WORKING PAPER

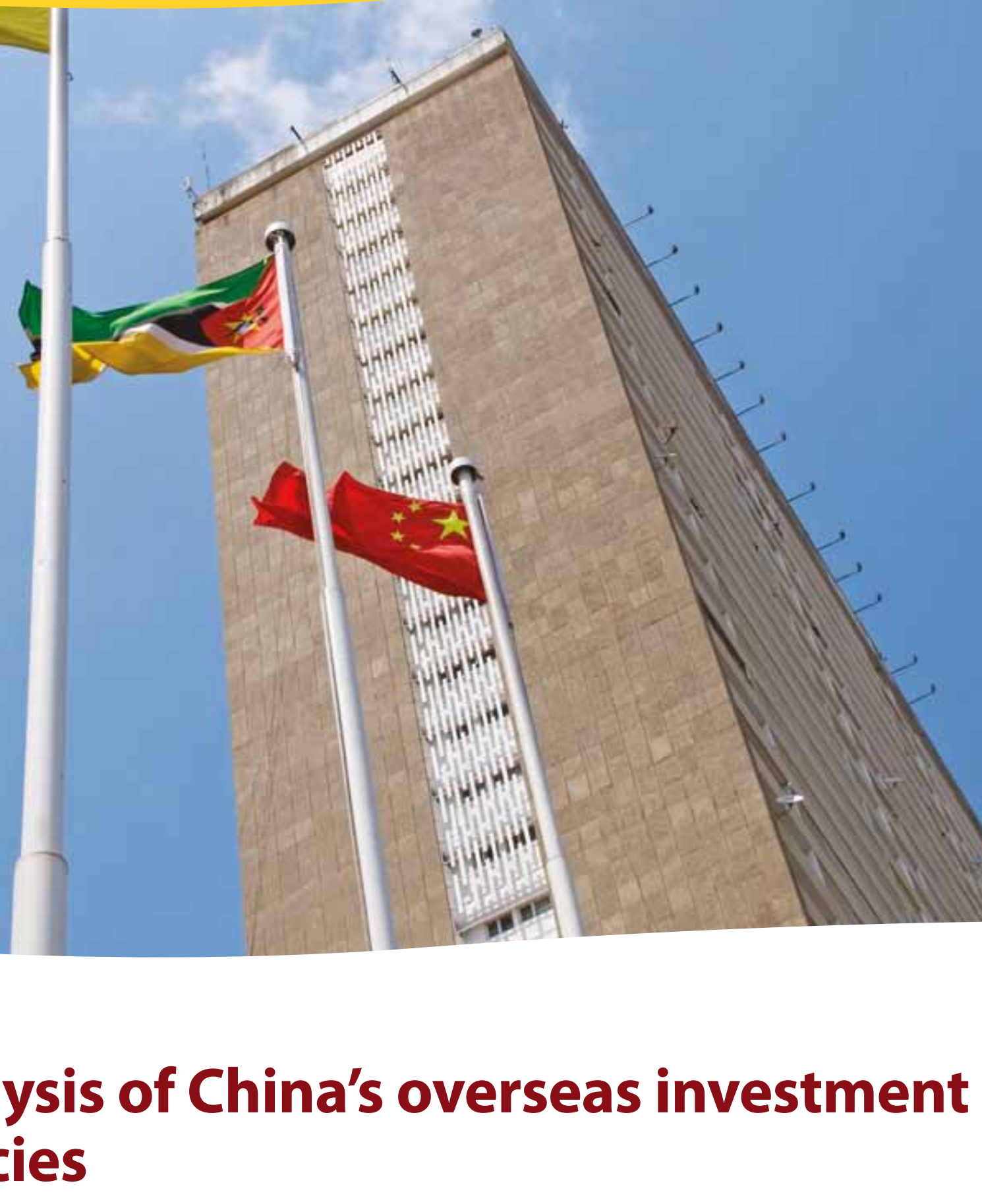

\title{
Analysis of China's overseas investment policies
}

Huang Wenbin

Andreas Wilkes

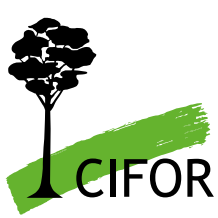



Working Paper 79

\section{Analysis of China's overseas investment policies}

Huang Wenbin

World Agroforestry Centre, China and East Asia Node, Beijing

Andreas Wilkes

World Agroforestry Centre, China and East Asia Node, Beijing 
Working Paper 79

(C) 2011 Center for International Forestry Research All rights reserved

Huang, W. and Wilkes, A. 2011 Analysis of China's overseas investment policies. Working Paper 79. CIFOR, Bogor, Indonesia.

Cover photo $\odot$ D.J. Clark

Horizon Chinese shopping centre that includes restaurants and a hotel in Maputo, Mozambique.

\author{
CIFOR \\ Jl. CIFOR, Situ Gede \\ Bogor Barat 16115 \\ Indonesia \\ $\mathrm{T}+62(251) 8622-622$ \\ $\mathrm{F}+62(251) 8622-100$ \\ E cifor@cgiar.org
}

\title{
www.cifor.org
}

Any views expressed in this publication are those of the authors. They do not necessarily represent the views of CIFOR, the authors' institutions or the financial sponsors of this publication. 


\section{Table of contents}

Abbreviations $\quad$ iv

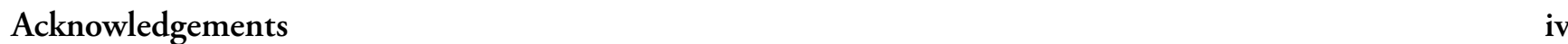

Summary $\quad v$

1 China's overseas investment flows 1

2 China's overseas investment policy actors $\quad 2$

2.1 Overview 2

2.2 The main policymaking agencies $\quad 2$

3 Stages in China's overseas investment policy development 5

3.1 Overview 5

3.2 Promotional measures $\quad 10$

3.3 Government special funds $\quad 12$

3.4 Credit support $\quad 13$

3.5 Taxation policies 14

3.6 Supervision and regulatory measures $\quad 15$

4 Discussion $\quad 18$

5 References $\quad 19$

Annexes

$1 \quad$ Policies to support privately owned companies in making overseas investments 21

2 Inventory of the main Chinese overseas investment policies 24

\section{List of figures and boxes}

\section{Figures}

1 China's overseas investment flows, 1982-2009 (billions USS) 1

2 China's OFDI management system 2

3 Proportion of overseas investment policy changes by various policymaking agencies 2

4 China's outward foreign direct investment policy development and flows, 1982-2009 6

5 Number of overseas investment policies issued per year (1983-2009) 7

Box

1 Extract from MOFCOM's country guide on DR Congo 


\section{Abbreviations}

BMZ Federal Ministry for Economic Cooperation and Development, Germany

CADFund China-Africa Development Fund

CBA China Banking Association

CBRC China Banking Regulatory Commission

CCPIT China Council for the Promotion of International Trade

CDB China Development Bank

CIFOR Center for International Forestry Research

CSRC China Securities Regulatory Commission

DRC Democratic Republic of Congo

EIA environmental impact assessment

FDI foreign direct investment

FOCAC Forum on China-Africa Cooperation

GIZ Gesellschaft für Internationale Zusammenarbeit

ICRAF World Agroforestry Centre

IMF International Monetary Fund

MEP Ministry of Environmental Protection

MFA Ministry of Foreign Affairs

MOF Ministry of Finance

MOFCOM Ministry of Commerce

MOFTEC Ministry of Foreign Trade and Economic Cooperation (name later changed to MOFCOM)

NBS National Bureau of Statistics

NDRC National Development and Reform Commission

NPC National Planning Commission (name later changed to NDRC)

OECD Office of Economic Co-operation and Development

OFDI outward foreign direct investment

PBC People's Bank of China

SAFE State Administration for Foreign Exchange

SASAC State Asset Supervision and Administration Commission

SAT State Administration of Taxation

SEPA State Environmental Protection Administration

SIA social impact assessment

SOE state-owned enterprise

UN United Nations

\section{Acknowledgements}

This working paper is a product of the project titled 'Chinese Trade and Investment in Africa: Assessing and Governing Trade-Offs to National Economies, Local Livelihoods and Forest Ecosystems'. The project has been supported by a grant from the German Federal Ministry for Economic Cooperation (BMZ) and Development through the Gesellschaft für Internationale Zusammenarbeit (GIZ) to CIFOR, and is implemented by CIFOR, the World Agroforestry Centre and the University of Leipzig. Research for this working paper was conducted by the World Agroforestry Centre's China and East Asia Node in Beijing. 


\section{Summary}

In recent years, in line with China's Going Out strategy announced in 2000, China's overseas investment activities have increased greatly and at increasing rates. By the end of 2009, the total value of China's outward foreign direct investment (OFDI) had reached US\$5.6 billion (MOFCOM, NBS and SAFE 2009). Policies have played strong supporting roles in bringing about this trend by facilitating and encouraging Chinese companies to make overseas investments. This working paper summarises these policies based on an analysis of policy changes over time and identifies the main drivers of these changes. It ends by highlighting some key research questions of relevance to deepening understanding of the impacts of Chinese trade and investment in Africa.

The frequency with which OFDI-related policies are issued is clearly linked with changes in the scale of OFDI investment. From 1979 to 2001, about four related policies were issued each year and overseas investments were limited. After China formally developed its strategy of Going Out in 2000, the frequency of policies increased, to more than 15 per year since 2002 . The main aim of relevant policies issued since 2002 has been to boost overseas development. Nevertheless, the foundations of China's OFDI management system were laid in previous periods.

Analysis of Chinese policy documents related to OFDI finds that a total of 26 central government agencies have been involved in issuing the policies. More than 50\% were issued by ministry-level agencies responsible for commerce and foreign exchange management, and $20 \%$ by agencies responsible for financial management, including the Ministry of Finance, the central bank and banking regulatory agencies.

Further research is needed to understand policy processes, particularly given changes in the context in which Chinese OFDI is taking place. Amongst the changes whose relevance and impact on policy processes are poorly understood are the new context created by the international financial crisis beginning in 2008 and policy responses to international initiatives and overseas regulations pertaining to social and environmental safeguards and standards. Despite the substantial number of policies issued, there has been to date almost no analysis of how feedback is obtained, such as learning from failed investments, or how government agencies monitor the implementation of policy requirements. Further research in these areas would enhance understanding of the relationship between China's OFDI activities and Chinese national policies.

The project 'Chinese trade and investment in Africa: Assessing and governing trade-offs to national economies, local livelihoods and forest ecosystems' project, launched in March 2010, aims to advance understanding of the social, economic and environmental impacts of Chinese investment in commodities or sectors affecting forests and livelihoods in Africa (e.g. timber, mining, agriculture), and to strengthen the capacity of decision-makers in government, civil society and the private sector to enact reforms to maximise social and economic benefits while minimising adverse effects. 


\section{摘要}

随着 “走出去” 战略的提出, 近年来中国的对 外投资活动逐渐增多, 保持了较快的发展速 度。根据中国《对外投资统计公报》的统计, 截至2009年底，中国对外投资金额已经达到了 56 亿美元。在这巨大成绩的背后, 政策起到了 非常重要的作用, 它推动和鼓励了中国企业开 展对外投资活动。鉴于此, 本文按照时间顺序 和变化趋势, 对这些政策进行了归纳总结, 并 明确了影响政策变化的主要驱动因素。文章的 最后, 还提出了与深化理解中国对非洲投资和 贸易影响有关的重点研究议题。

通过分析可以发现, 中国对外投资相关政策的 发布频率与对历年外投资规模有着密切的联 系。1979年至2001年间, 平均每年所发布的 投资政策只有 4 部，对外投资的规模也非常有 限。进入2000年, 在正式提出 “走出去” 战略 之后, 政策发布的频率开始增加。从 2002 年开 始, 每年的平均数量达到了15部之多。这些相
关政策主要目标是推进海外投资的发展，同时 他们也为中国对外投资管理体系的建立奠定了 基础。

同时, 一共有 26 个中央政府部门参与发布了这 些政策。其中 $50 \%$ 由负责商业和外汇管理的部委 颁发，20\%由负责金融管理的部门颁发（如商务 部、央行和银监会）。

此外，了解政策制定和发布的过程可成为今后 进一步研究方向, 尤其是能够影响中国对外投 资的一些重要变化因素。其中包括始于 2008 年 的国际金融危机, 以及与社会和环境保护措 施、标准有关的国际倡议和规定, 他们均可以 对政策的变化产生影响。同时, 目前还缺乏对 政策反馈机制的分析, 如投资失败的反馈, 政 府部门如何监督政策的实施等。这些研究可进 一步加深对中国对外投资活动和国家政策之间 的关系了解。 


\section{Résumé}

Ces dernières années, conformément à la stratégie chinoise d'internationalisation ("Going out ») annoncée en 2000, les activités d'investissement de la Chine à l'étranger ont augmenté de manière considérable et de plus en plus rapidement. Fin 2009, la valeur totale des investissements directs à l'étranger (IDE) du pays avait atteint 5,6 milliards de dollars américains (MOFCOM, NBS et SAFE 2009). Les politiques ont joué un rôle important en faveur de cette tendance, en facilitant et en encourageant les sociétés chinoises à investir à l'étranger. Ce document de travail résume ces politiques en se basant sur une analyse des changements de politique au fil du temps, et identifie les principaux facteurs de ces évolutions. Il conclut en soulignant certaines des grandes questions de recherche pertinentes pour approfondir la compréhension des effets du commerce et des investissements chinois en Afrique.

La fréquence à laquelle les politiques d'IDE sont élaborées est clairement liée à l'évolution de l'ampleur des IDE. Entre 1979 et 2001, environ quatre politiques étaient émises chaque année et les investissements à l'étranger étaient limités. Après avoir officiellement développé sa stratégie d'internationalisation, en 2000, la Chine a augmenté la fréquence de ces politiques, pour dépasser les 15 par an depuis 2002, le principal objectif de celles-ci étant de stimuler le développement à l'étranger. Toutefois, les fondations du système de gestion des IDE chinois ont été posées au cours des périodes précédentes.

L'analyse des documents de politique chinois liés aux IDE révèle qu'un total de 26 agences du gouvernement central sont engagées dans l'élaboration des politiques. Plus de $50 \%$ de ces politiques ont été émises par les agences ministérielles chargées de la gestion du commerce et des devises, et $20 \%$ par des agences chargées de la gestion financière, notamment le Ministère des finances, la Banque centrale et les agences de réglementation bancaire.

D'autres recherches sont nécessaires pour comprendre les processus politiques, compte tenu en particulier de l'évolution du contexte dans lequel les IDE chinois sont réalisés. Parmi les évolutions dont l'importance et l'effet sur les processus politiques sont mal compris, on peut citer le nouveau contexte créé par la crise financière internationale qui a débuté en 2008 , ainsi que les réponses politiques aux initiatives internationales et aux réglementations étrangères relatives aux normes et aux mesures de sauvegarde sociales et environnementales. Malgré le nombre important de politiques émises, il n'existe à ce jour pratiquement aucune analyse de la manière dont les retours sont obtenus, par exemple les enseignements tirés des investissements ayant échoué, ou la manière dont les agences gouvernementales surveillent la mise en œuvre des exigences des politiques. D'autres recherches dans ces domaines amélioreraient la compréhension des rapports entre les activités d'IDE de la Chine et les politiques nationales du pays.

Le projet " Chinese trade and investment in Africa: Assessing and governing trade-offs to national economies, local livelihoods and forest ecosystems " (Le commerce et les investissements chinois en Afrique : évaluation et gestion des compromis pour les économies nationales, les moyens de subsistance locaux et les écosystèmes forestiers »), lancé en mars 2010, a pour objectif de mieux comprendre les conséquences sociales, économiques et environnementales des investissements chinois dans les matières premières ou les secteurs qui affectent les forêts et les moyens de subsistance en Afrique (p. ex. le bois, le secteur minier, l'agriculture), et de renforcer les capacités des décideurs du gouvernement, de la société civile et du secteur privé à adopter des réformes qui maximisent les avantages sociaux et économiques tout en minimisant les effets négatifs.

Ces dernières années, conformément à la stratégie d'internationalisation de la Chine annoncée en 2000 (CCPIT 2007), les activités d'investissement de la Chine à l'étranger ont augmenté de manière considérable et de plus en plus rapidement. Fin 2009, la valeur totale des investissements directs à l'étranger (IDE) du pays avait atteint 5,6 milliards de dollars américains (MOFCOM, NBS et SAFE 2009). Les politiques ont joué un rôle important en faveur de cette tendance, en facilitant et en encourageant les sociétés chinoises à investir à l'étranger. Ce document de travail résume ces politiques en se basant sur une analyse des changements politiques au fil du temps, et identifie les principaux facteurs de ces évolutions. Il conclut en soulignant certaines des grandes questions de recherche pertinentes pour approfondir la compréhension des effets du commerce et des investissements chinois en Afrique. 



\section{China's overseas investment flows}

Chinese overseas investment flows during the past 30 years can be divided into three distinct phases.

Phase 1, 1979-1990, initiation During this phase, China emerged from the political impacts of the Cultural Revolution and reformulated its national development strategy to focus on developing and modernising the economy (Voss et al. 2008). Although increasing market liberalisation and encouragement of private enterprise characterised the 1980s and 1990s, within the general rubric of the 'socialist market economy' reform process, most companies continued to operate within the framework of the state economic planning system and their activities were restricted by government regulations. The government treated overseas investments cautiously, and only certain selected state-owned companies had the opportunity to make overseas investments (Voss et al. 2008). In addition, during this period, foreign exchange reserves were limited and overseas investment activities were very rare (Chen 2009). As a result, levels of investment flows were low, averaging less than US $\$ 0.9$ billion per year (Figure 1).
Phase 2, 1991-2001, unstable development. During this period, the total amount of overseas investment greatly increased, but since it was not a priority economic activity driving economic growth in China, investment flows were volatile with large fluctuations across years. The value of overseas investments made in 1991 was a little over US $\$ 0.9$ billion, but in 1992 this more than quadrupled to $\$ 4$ billion. This level remained constant in 1993, but in 1994 it dropped by $50 \%$ to $\$ 2$ billion. Over the following four years (19951998), it increased steadily, but then in 1999 it fell back sharply to the 1991 level (Figure 1). Multiple complex factors contributed to this volatility, but changes in policies during this period had an important impact.

\section{Phase 3, 2002-present, rapid and steady} development In 2000 China's central government formally announced the Going Out strategy, implementation of which has played a role in stimulating Chinese overseas investment in recent years. OFDI flows have greatly increased during this period, from US $\$ 2.5$ billion in 2002 to $\$ 56.5$ billion, an increase of more than 2000\% (Figure 1).

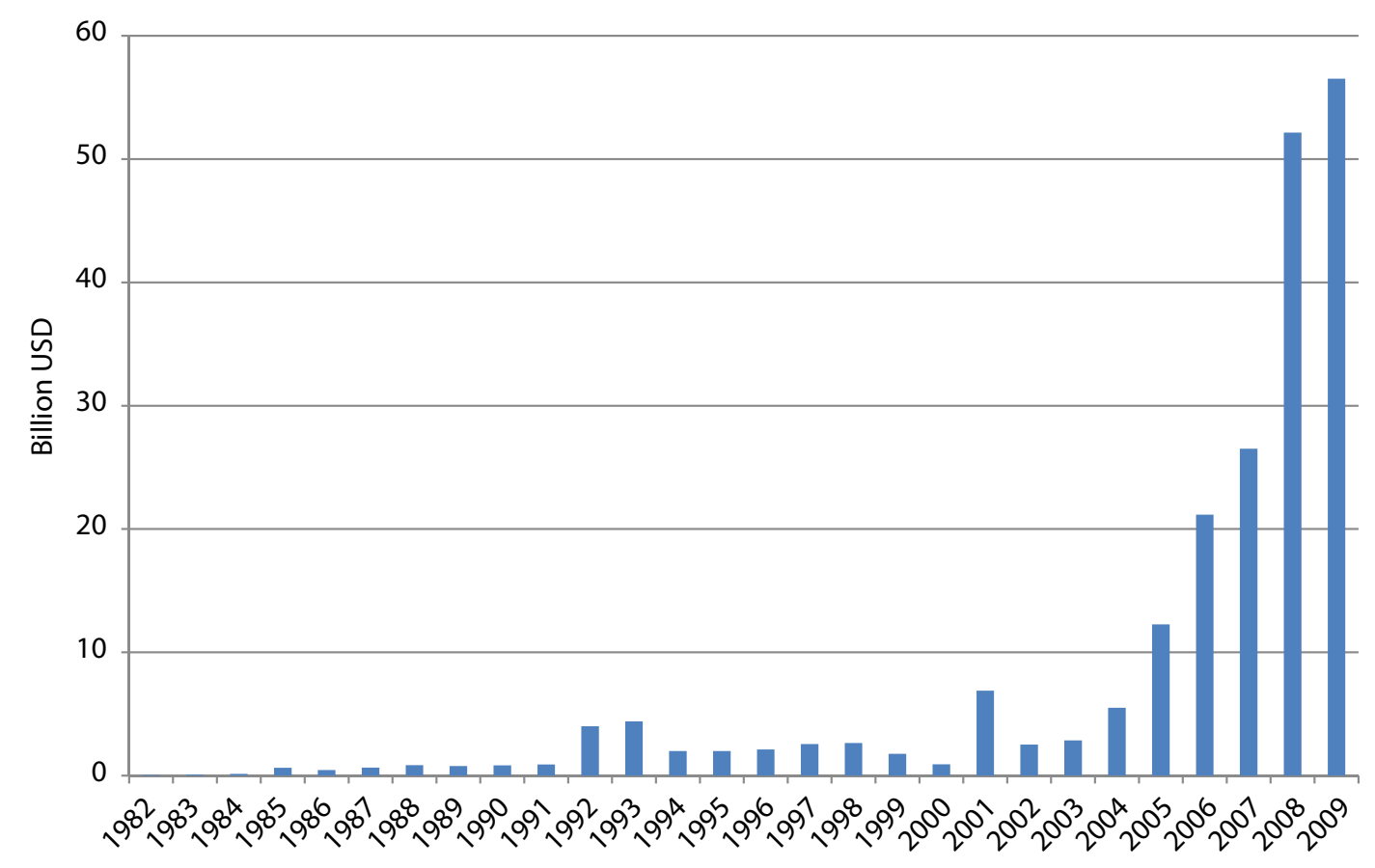

Figure 1. China's overseas investment flows, 1982-2009 (billions USS)

Sources: Data for 1982-2002 based on UNCTAD World Investment Reports; data for 2003-2009 are from the Bulletin of China's outward foreign investment (published by MOFCOM, NBS and SAFE), compiled by the authors. 


\section{China's overseas investment policy actors}

\subsection{Overview}

A number of central government administrative departments in China are responsible for formal policymaking. A compilation of policies on overseas investment and an analysis of the agencies responsible for issuing these policies indicate that 26 central government agencies have been involved in the policymaking process.

These central government agencies can be classified into four general levels (Figure 2). The top decisionmaking agency is the State Council, which is responsible for overall management of China's government and significant decisions affecting the economy and society. The second level is made up of the core ministry-level agencies involved in overseas investment management: the Ministry of Commerce (MOFCOM) and the State Administration for Foreign Exchange (SAFE). These agencies developed most of the policies analysed in this working paper. Given its importance, the National Development and Reform Commission (NDRC), which historically had key responsibilities for approving overseas investments and was informally called the 'small State Council', may also be considered part of this second level.

The third level consists of functional departments responsible for various fields such as finance and taxation. Their roles are mainly to assist the core

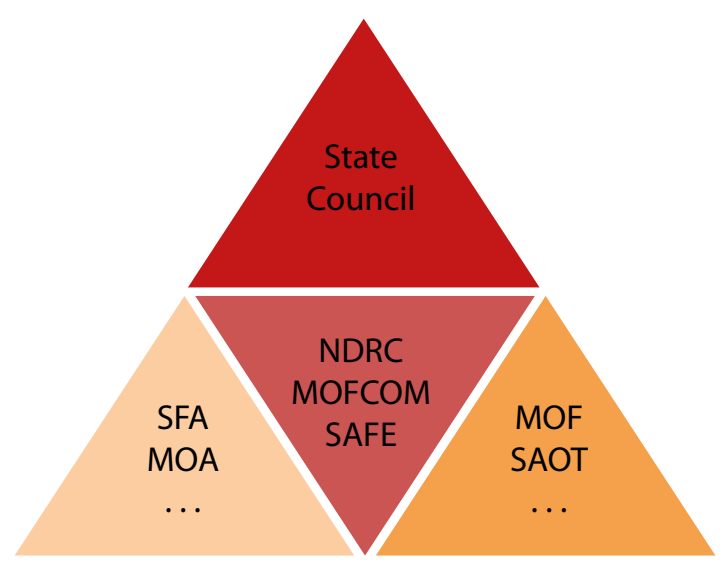

Figure 2. China's OFDI management system

SFA is State Forestry Administration, MOA is Ministry of Agriculture, SAOT is State Administration of Taxation ministries to ensure that the policies are coordinated with other existing policies, and to assist in issuing and implementing the policies. The fourth level comprises line ministries, such as those responsible for mining, agriculture and forestry. Each of these ministries is in charge of policies in its own sector but is less influential in determining overseas investment policy affecting its sector. In addition to the above, departments subordinate to each ministry at the provincial level also play important roles, as they are the primary agencies charged with executing these policies.

An examination of the roles of each agency in issuing relevant policies during the past 30 years shows that MOFCOM and SAFE are the most important agencies, having issued more than $50 \%$ of these policies. ${ }^{1}$ If the NDRC is included as a core ministerial agency, then this second level of authority accounts for $56.1 \%$ of the total number of OFDI-related policies issued. Although the State Council issued only $5.9 \%$ of policies, its influence is tremendous. Departments in the third level - the Ministry of Finance (MOF), China Securities Regulatory Commission (CSRC) and the People's Bank of China (PBC) - are also important, accounting for nearly $20 \%$ of the policies issued (Figure 3).

\subsection{The main policymaking agencies}

State Council. The State Council is the highest ranking organ in the central government. It is responsible for drafting and developing policies, law and regulations as well as for coordinating national economic development. The State Council makes major economic strategy and policy decisions, although the specific policy measures may be issued by subordinate organs such as SAFE or MOFCOM (Zhao 2006).
1 The names of these agencies have changed over time. The analysis in this working paper uses the name of each as of 2011, even though the policies were issued under the name current at the time of issue. 


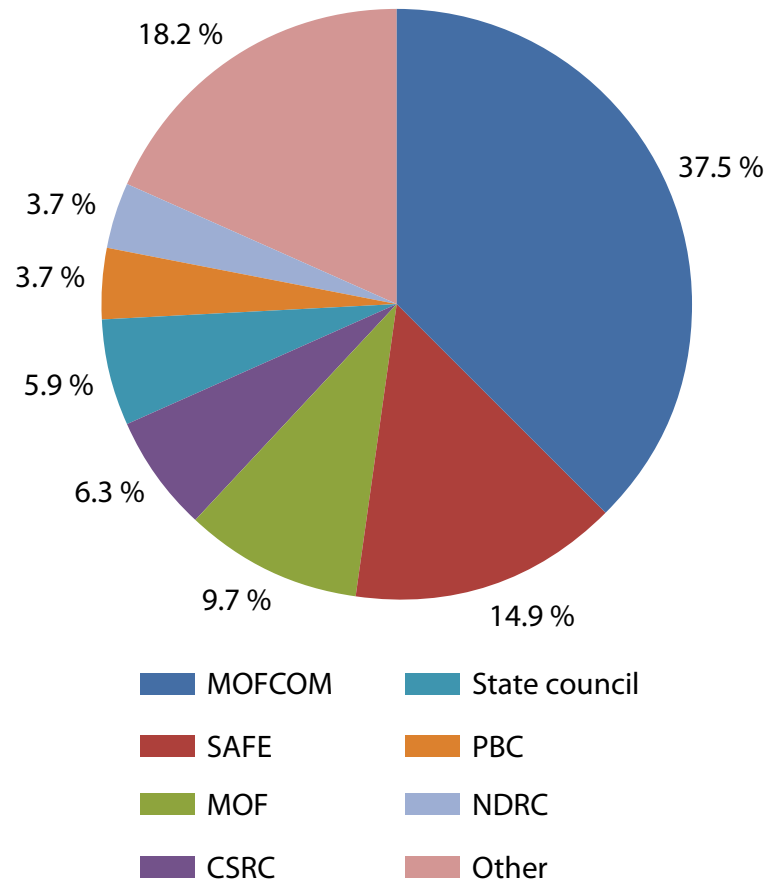

Figure 3. Proportion of overseas investment policy changes by various policymaking agencies

Source: Compiled by the authors

Ministry of Commerce (MOFCOM). $\mathrm{MOFCOM}^{2}$ was established with its current form and mandate in 2003. MOFCOM's main responsibilities with regard to Chinese OFDI are:

- supervision of Chinese OFDI by drafting and implementing policies and regulations, and by considering applications for approval of nonfinancial OFDI projects;

- bilateral and multilateral negotiations on investment and trade treaties and representing China at the World Trade Organization and other international economic organisations;

- ensuring the alignment of China's economic and trade laws with international treaties and agreements; and

2 MOFCOM evolved from the Ministry of Foreign Trade and Economic Cooperation (MOFTEC) and in 2003 became responsible for domestic trade, foreign economic coordination and the coordination of activities related to international trade in industrial products, raw materials and semifinished products by the State Economic Trade Commission and the State Development and Planning Commission (Munro and Yan 2003). MOFTEC was the successor organisation to the Ministry of Foreign Economic Relations and Trade (MOFERT) following its reorganisation in 1993. For simplification, we use the name MOFCOM throughout while acknowledging that the three organisations varied in terms of their specific responsibilities and scope of functions.
- coordinating China's foreign aid policy and other related funding and loan schemes (Munro and Yan 2003).

These functions provide MOFCOM with direct and indirect opportunities to guide and influence the scope and direction of Chinese OFDI (Zhang 2003).

State Administration of Foreign Exchange (SAFE). SAFE was established in 1979 under the Bank of China and is responsible for administering the use and flow of foreign exchange (Shan 1989, Lin and Schramm 2003, Zhang 2004). ${ }^{3}$ SAFE consolidated activities and responsibilities that were formerly distributed across several ministries in relation to the supervision of China's foreign exchange controls (Lin and Schramm 2004). Although authority over SAFE was moved in 1982 from the Bank of China to the newly created central bank, the People's Bank of China (PBC), SAFE remained relatively independent until a later government restructure in 1998 (Shi and Gelb 1998, Lin and Schramm 2003). This restructure led to SAFE strengthening its OFDI-related mandate in four ways:

- assuming responsibility for reporting balance of payments data to the State Council and the International Monetary Fund;

- making foreign exchange policy recommendations to the People's Bank of China;

- overseeing the transfer of foreign exchange out of and into China under the capital account of the balance of payments; and

- managing China’s foreign exchange reserves (Zhang 2004).

\section{National Development and Reform Commission}

(NDRC). The NDRC is sometimes referred to by its previous name, the State Development and Reform Commission, which emerged from the institutional structure of the State Planning Commission (Munro and Yan 2003). The NDRC is the main government body that designs, regulates and coordinates national economic development and industrial policy. Its functions include regulating government investments

3 SAFE evolved from the State Administration of Exchange Control (SAEC) in 1994, which itself succeeded the State General Administration for Exchange Control (SGAEC) in 1982 (IMF 1983, Shan 1989, Bumgarner and Prime 2000). For simplicity, this paper uses the term SAFE throughout, while acknowledging that the three organisations had different responsibilities and scope. 
in domestic industries (Pearson 2005) and developing 'strategies, goals and policies to balance and optimize China's overseas investments' (Munro and Yan 2003: 4). Within this role, the NDRC has issued guidelines concerning access by domestic firms to soft loans to finance their internationalisation (Schwartz 2005). In a similar vein, the NDRC, in cooperation with MOFCOM, published a host country catalogue that lists the countries for which the Chinese government subsidises FDI projects (Zweig and Bi 2005). The NDRC is also involved in the approval process for Chinese OFDI. Large-scale Chinese OFDI projects in industrial sectors such as natural resources and other projects involving large sums of foreign exchange need prior investment approval from the NDRC.

Ministry of Finance (MOF). MOF was established in 1949. Its main responsibilities include:

- drafting development strategies, plans and policies for China's fiscal and taxation sectors, and cooperating in the development of macro-economic policies based on forecast economic trends;

- drafting laws and regulations regarding fiscal, taxation and accounting management; and

- managing the central government's revenue and expenditures, including preparing the annual budget, supervising its use and reporting to the central government.

MOF is also in charge of negotiations and agreements regarding China’s overseas fiscal activities, such as debt.

People's Bank of China (PBC). The PBC was established as China's central bank in 1983 and is currently directly supervised by the State Council (Zhang 2004). The PBC is responsible for overall financial policies and rules and for dealings with international financial organisations such as the World Bank. It also supervises and manages China's foreign exchange reserves. The PBC imposed significant changes on China's foreign exchange management system in 1994, changes which gave the PBC tighter foreign exchange controls. With its combined authority over domestic monetary and financial policies and foreign exchange control, the PBC gained the ability to arbitrage between these functions. Careful management of China's foreign exchange reserves used in international investment projects by Chinese companies has helped the $\mathrm{PBC}$ to achieve several domestic monetary objectives, including a stable and low inflation rate, because domestic enterprises could be encouraged to spend yuan to reduce pressure on the monetary supply side (Pettis 2005). Prior to 1992, the PBC regulated the financial services sector and hence the foreign investments of financial institutions. In 1992, securities, insurance and banking services were spun off into separate regulatory authorities, one of which is the China Banking Regulatory Commission, which today approves OFDI projects by Chinese banks (Pearson 2005).

China Securities Regulatory Commission (CSRC). The CSRC was established in 1990 as a ministerial agency responsible for the overall management of the country's security and futures markets. In relation to China's OFDI it is responsible for approving and supervising Chinese companies' overseas stock issues and debenture activities, stock market listings and related financial activities. Although the CSRC is the main management agency, its real role in supervising overseas listings is limited to making suggestions and providing coordination. Most of the supervisory work is undertaken by the responsible departments in the location of listing (Liao 2009).

The information disclosure system for enterprise listing has been improved since China's security market was established. The system now operates under the Securities Act of 2006, which requires several forms of information disclosure: publication of a summary prospectus; timely reporting (including annual and interim reports); reporting of key events (e.g. mergers and acquisitions); reporting by directors and senior managers to shareholders; and reporting of information required by stock exchange corporations (Liao 2009).

Companies listed overseas are included in this system. The requirement for Chinese companies to meet the information disclosure regulations in the country of listing is affirmed in the CSRC document 'Several opinions about further implementing information disclosure by overseas listed companies'. The CSRC publishes reports on listed enterprises on its official website, which also has lists of overseas and domestic listed companies. 
State Asset Supervision and Administration Commission (SASAC). SASAC was established by the State Council in 2003 to represent the Chinese government in non-financial state-owned enterprises (SOE). As the Chinese government is the ultimate owner and investor in state-owned companies, SASAC has wide-reaching responsibilities and powers (Pearson 2005, Naughton 2007). Prior to SASAC's establishment, its functions were divided between the State Economic Trade Commission and several ministries and other government authorities that controlled and supervised companies within their respective sectors. This sometimes created competition among state-owned companies (Mueller and Lovelock 2000, Munro and Yan 2003, Pearson 2005).

SASAC's objective as an investor is to ensure that the state-owned companies under its supervision remain competitive and increase their profitability and the value of the assets under their control (Pearson 2005). However, it remains questionable whether such an institution can achieve this type of objective (Clarke 2003) because its supervision is split: the national SASAC directly controls more than 120 national state-owned companies while subnational SASACs act at a provincial level (Naughton 2006, 2007). Both levels of SASAC exercise their power by appointing senior managers to state-owned companies and by involvement in major decision making of firms under their control (Naughton 2007). A considerable number of senior management positions are actually appointed directly by the Chinese Communist Party (Naughton 2007). This structure and the strong influence of the Party do not necessarily lead to the appointment of the most suitable managerial candidates, and this has several implications for companies' domestic and international operations. OFDI projects by stateowned companies under the supervision of SASAC are unlikely to be decided without the explicit approval of SASAC. The decision to invest overseas, through either greenfield investment or acquisition, can be regarded as a major decision that affects the company's profitability and the value of the involved assets. Any OFDI project by a state-owned enterprise (SOE) therefore touches upon SASAC's key objectives.

Examples of Chinese firms under the direct control of SASAC investing overseas include the following seven SOEs. These all rank among the top 100 developing country multinational enterprises (UNCTAD 2006): China National Offshore Oil Corporation (CNOOC), China National Petroleum Corporation (CNPC), Sinochem Corporation, China State Construction Engineering Corporation, China Minmetals Corporation, China Cereals, Oils and Foods Company (COFCO) and TCL (through SASAC's holdings in Huizhou Municipal Investment Holdings). SASAC also controls smaller SOEs such as China Aviation Oil, which has operations in Singapore, and the international trading company Sinosteel.

\section{Stages in China's overseas investment policy development}

\subsection{Overview}

The frequency with which China's overseas investment policies are issued and their strategic direction have varied over time. In the first two stages, from 1979 to 2001, the frequency of new policies was low, at around four per year. The economic planning system led to restrictive management processes and a lack of investment resources, resulting in very limited investment activities. However, overseas investment gradually became a greater focus in the national economy, and China formally developed its strategy of Going Out. Since this strategy was announced in 2000, OFDIrelated policies have been issued more frequently - increasing to more than 15 per year since 2002 (Figure 3). Most of these policies were designed to boost overseas investment.

Phase 1, 1979-1990. From a policy perspective, this phase can be divided into two periods. The period 1979 to 1982 was a tentative phase. China formally recognised the legal status of international investments and made some attempts at investing overseas. This is reflected in the State Council's 'Fifteen economic reform measures' issued in 1979, in which the 13th measure explicitly allowed companies to establish firms overseas (Lu 2002). During the period 1983 to 1990 , the government actively encouraged overseas investment, publishing several favourable policies that facilitated companies' 


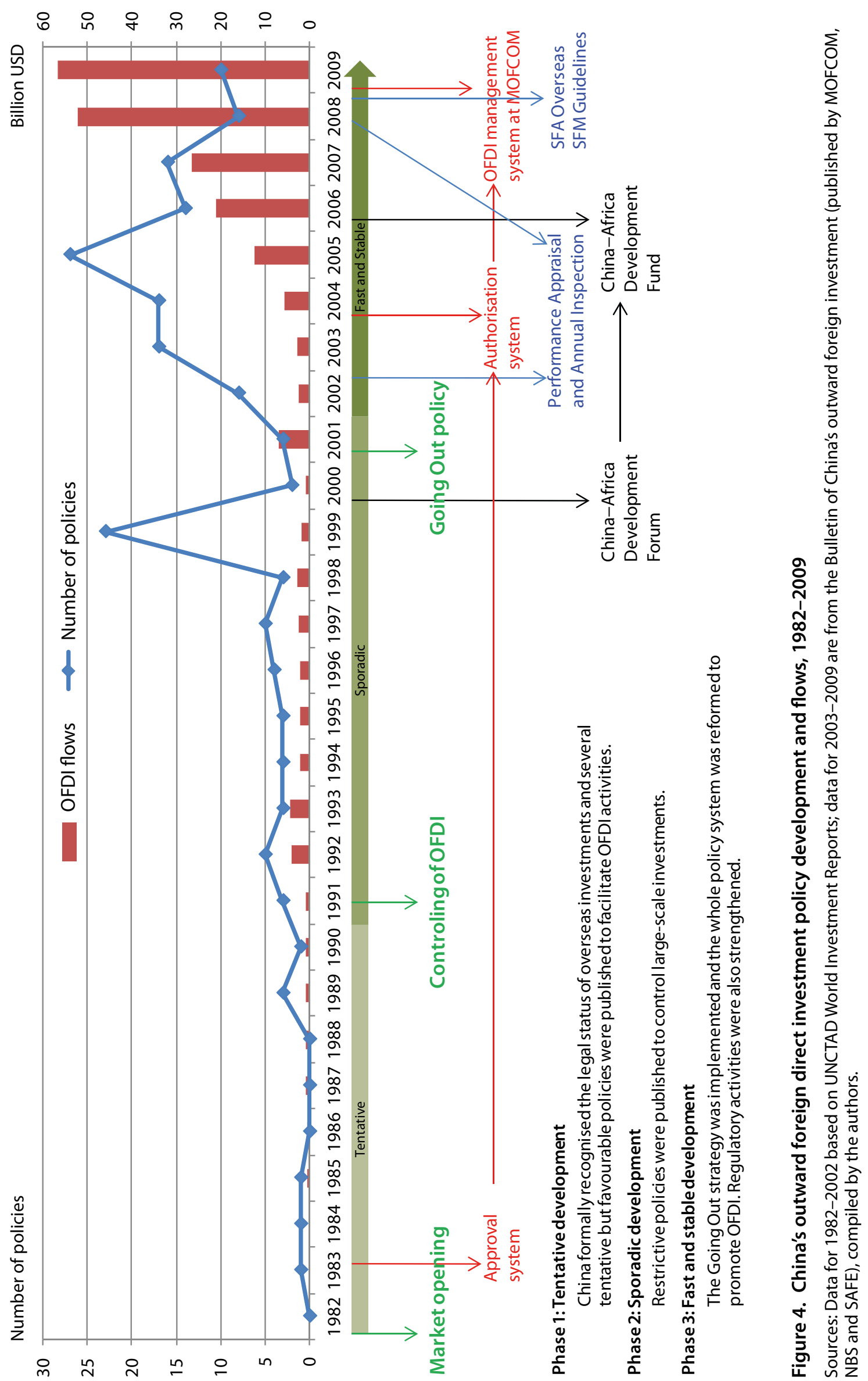




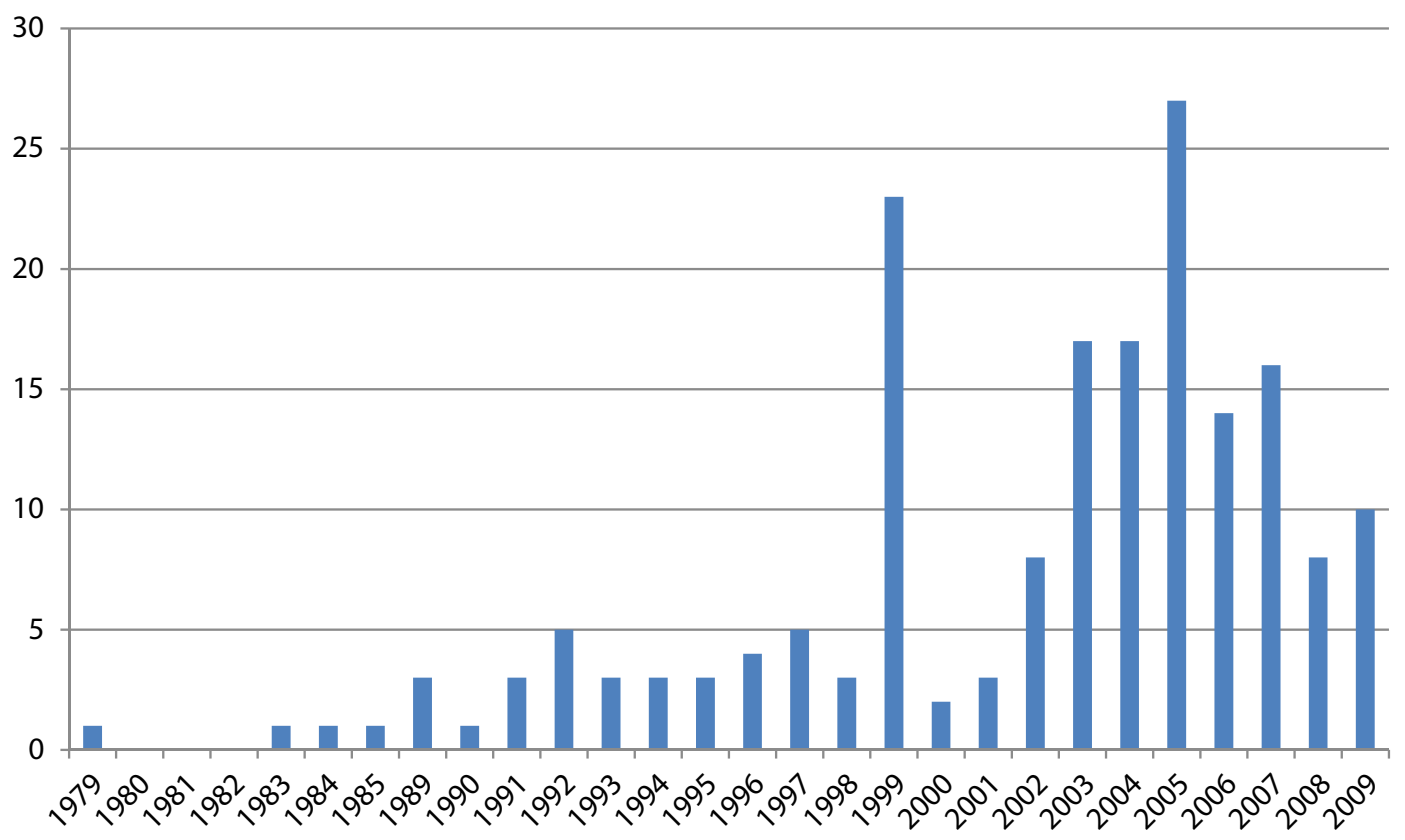

Figure 5. Number of overseas investment policies issued per year (1983-2009)

Source: Compiled by the authors

investment activities. These policies also laid the preliminary foundations for the overseas investment management system in place today.

In 1983, the State Council designated the Ministry of Foreign Trade and Economic Cooperation (MOFTEC) the predecessor of MOFCOM, as the approving authority for OFDI, and preliminarily set the procedure for enterprises to make overseas investment. In 1985, to simplify the procedures and reduce approval time, MOFTEC published 'Approval procedures and administrative method for establishing non-trade management joint ventures overseas', which defined the procedures for applying for and approving overseas investments. MOFCOM and the superior authorities (provincial governments, related ministries etc.) of the investing companies were the agencies responsible for granting approval based on the importance of the investment; consultation with the responsible agencies of the investment destination was also necessary. For example, MOFCOM was responsible for approving projects valued at more than US $\$ 1$ million; projects below this value were the responsibility of the relevant department within the company. To apply, companies needed to complete complicated procedures and submit, among others, the project proposal, a feasibility report and the company by laws.
SAFE's function in foreign exchange management determined its role in overseas investment. SAFE published the systematic policy 'Foreign exchange management method for overseas investments' in 1989 and issued implementation regulations in 1990. These documents established the foreign exchange management system for Chinese overseas investments and established the key role of SAFE in approving overseas investments both before and after their approval by MOFCOM. Before a company could seek approval from MOFCOM, SAFE would review its foreign exchange resources and evaluate the investment risk based on the resources certification provided by the company. After gaining permission from MOFCOM, when transferring the foreign exchange abroad, the company had to lodge several documents with SAFE, including the MOFCOM approval document, the findings of the foreign exchange resources review, the project contract and certification material related to the foreign exchange amount. SAFE also required that companies keep $5 \%$ of their foreign exchange as a profit deposit. This regulation was in force for more than 10 years and had a strong influence on foreign exchange management.

To strengthen accounting administration, in 1989 the $\mathrm{PBC}$ published 'Temporary management method for foreign trading, financial and insurance 
companies', and the MOF published 'Temporary method for non-trade foreign exchange accounting management for overseas units'. These regulations defined the scope of state-owned capital, benefitsharing methods and accounting management procedures for companies with overseas investments, and supplemented the emerging overseas investment management system.

These policies partly explain the only slight increase in overseas investment by China in the 1980s. The strict and complicated application and approval procedures limited the enthusiasm of Chinese companies to a certain extent. On the other hand, these policies laid the foundations for China's overseas investment management system. MOFCOM and SAFE were identified as the main actors and they continued to exert their influence over the next 20 years.

Phase 2, 1991-2001. This phase also can be separated into two periods: 1991-1998 and 19992001. In the first period, the Chinese government published several restrictive policies and strengthened control over large-scale investments. In the second period, the strategy to 'Develop international economy cooperation and trade' was initiated and related policies were published. This stimulated the development of overseas investment in processing and assembly businesses.

1991-1998. From 1989 to 1992 , reaction to the overheated economy resulted in recession and high inflation. Under these economic conditions, China's government began to adjust the economy and implemented policies to limit imports and encourage exports and to control the scale of domestic investment. Meanwhile, it was realised that the number of failed overseas investments was increasing, and a lack of controls resulted in some serious losses of state-owned capital. In response, in 1991 the State Council published an 'Opinion on the National Planning Commission reinforcing control of overseas investment projects' in order to control the scale of overseas investments; this document set the trend in OFDI over the next seven years (Chen 2009).

In particular, this policy tightened requirements for approval of large-scale investments, and the application and approval procedures were completely changed. Some of the approval rights for overseas investments were transferred from MOFTEC to the National Planning Commission (NPC), ${ }^{4}$ and the State Council also became part of the approval management system. The policy made the NPC responsible for reviewing investment project proposals and project feasibility reports for ordinary projects (to a value of less than US $\$ 1$ million), with the State Council taking responsibility for approving significant projects (more than $\$ 30$ million). MOFCOM was responsible only for reviewing the project contract and the bylaws of the companies and for issuing the approval document. For projects valued at less than $\$ 1$ million, the provincial government could appoint its subordinate departments to review and approve the proposal, which should be submitted to and filed by NPC also. These regulations greatly affected large overseas investments but gave small projects more room to manoeuvre. Under the influence of these regulations, MOFTEC, SAFE, the NPC and SASAC published policies separately to control overseas investments.

In 1991, the NPC published 'Regulations on developing and approving project proposals and feasibility reports for overseas investments'. These regulations announced the NPC's important role in approving overseas investments. The approval implementation regulations from the State Council and the importance of developing and approving investment project proposals and feasibility reports were also emphasised in these regulations.

As a response to the 'Opinion' of the State Council, in 1991 SAFE published the 'Circular to unify the specification of overseas investment risk and foreign exchange resource reviews', which standardised the application materials required for review. They also published the 'Specification of overseas investment risk and foreign exchange resource reviews' in 1993 to adjust the foreign exchange approval procedures based on the 'Opinion'. In 1992, MOFTEC published 'Temporary regulations on approval and management for establishing non-trade overseas companies' to strengthen control over non-trade overseas companies. SASAC also published the 'Temporary management method for overseas stateowned assets' and related implementation regulations to strengthen the supervision of overseas state-owned

4 A forerunner of the NDRC. 
assets. MOF published the 'Temporary method on overseas accounting management' in 1996 to regulate and supervise the accounting management of overseas projects.

During this period, investments in the newly independent Eastern European countries were encouraged for both economic and political reasons. Markets in these countries were seen as a good opportunity for China's economy. Furthermore, it was believed that improved relationships with these countries could help consolidate China's political status. All of these factors were reflected in the 'State Council suggestion on strengthening economic and trade relationships with former Soviet countries', issued in 1992, which encouraged Chinese companies to engage in international trade and investment in that region.

1999-2001. This was a transition period which incubated China's Going Out strategy. With China coming to appreciate the importance of overseas investment and seeing its potential to drive domestic economic development, the government issued many favourable policies.

\section{Encouragement of overseas processing and} assembly operations. Outward trade was an important economic growth point for China and its contribution to China's economy was increasing. However, the Asian Financial Crisis in 1997 seriously affected China's exports, as market demand in Southeast Asia fell in the second half of 1998. The weak currencies of these countries reduced the competitiveness of Chinese products because of the relatively strong yuan. To address this situation while also driving the development of the domestic economy, China's government developed a strategy that aimed to make use of cheap overseas labour resources and raw materials to drive exports; this strategy indirectly boosted overseas investment (Fang 1999).

In 1999, the State Council published 'Opinion on encouraging companies to carry out overseas material processing and assembly'. The core concept of this policy was to make use of China's advantages in some industries to promote exports and to accelerate adjustments to the industrial structure. The wording 'going out' was first mentioned in this document.
In this policy document, to encourage overseas processing and assembly, the approval rights for this overseas investment mode were returned from the NPC to MOFTEC, a transfer which also overcame some previously strict limitations (Chen 2009). From then on, overseas investment in this field increased, and overseas processing and trade became a new economic growth point for China. Subsequently, MOFTEC and other related departments published 12 policies to encourage companies to develop overseas processing and assembly operations, each policy addressing different aspects such as finance and fiscal and taxation issues.

Suggestion of the Going Out strategy. In 2000, the Fifth Plenary Session of the 15th Congress of the Chinese Communist Party was held, which issued the 'Suggestion to develop the $11^{\text {th }}$ Five Year Plan for national economic and social development'. It was decided at this event to initiate the Going Out strategy. The 'Suggestion' listed four main investment types that were to be encouraged (processing, trade, resources extraction, project contracting) and proposed to give overseas investments policy support through credit, insurance and other facilitative services. The $11^{\text {th }}$ Five Year Plan outlined policy directions for the following 5 years and created a sound environment for overseas investment (CITPC 2007).

In 2001, the Going Out strategy was incorporated into the 'Outline of the $11^{\text {th }}$ Five Year Plan for national economic and social development', which highlighted seven needs:

- to encourage overseas investments to enhance China's competitiveness and expand the scope and modalities of China's international economic and technical cooperation;

- to continue to develop overseas project contracting and labour service cooperation, and encourage competitive companies to explore processing and trading overseas, thereby promoting export of products, services and technology;

- to support companies in exploring resources overseas that were in short supply domestically and promote adjustment of the sectoral structure of resources trade;

- to encourage the use of foreign intellectual property resources to establish research and development and design operation centres overseas; 
- to support capable companies in developing transnational operations to achieve internationalised development;

- to improve the overseas investment service system and create a good investment environment for companies through improvements in systems governing finance, insurance, foreign exchange, taxation, intellectual property rights, laws and regulations, information services and entry and exit management; and

- to improve corporate governance structures and internal regulatory mechanisms to regulate and supervise overseas investments.

This document marked the birth of China's Going Out strategy and the comprehensive development of China's overseas investments. It also set the trend for policies in the succeeding 10 years and began a new chapter for overseas investment by China. Supported by this new strategy, overseas investment grew significantly, attracting the attention it receives today.

Phase 3, 2002-present. In 2002, the $16^{\text {th }}$ National Congress of the Chinese Communist Party was held in Beijing. At this meeting, then President Jiang Zemin emphasised the importance of the Going Out strategy. He described it as a 'significant event' within the longer-term national reform and liberalisation strategy, and he encouraged and supported companies with comparative advantages to make overseas investments in order to promote commodities and labour service exports as a means of establishing competitive multinational companies and international brands.

Based on the report of the $16^{\text {th }}$ Congress, China reformed its overseas investment policy system and published a set of policies to further stimulate the development of China's overseas investments. With the implementation of these positive policy measures, China also strengthened its regulatory activities and took measures to improve the profitability of Chinese overseas companies, especially from 2006 onwards. The number of failed investments increased during these years, including high-profile investments by China Aviation Oil in 2004, CITIC Pacific in 2008 and Sinosteel in 2009. In general, however, policies issued during this period tended to be highly favourable to OFDI. The next section summarises policies issued in this period.

\subsection{Promotional measures}

\section{Reform of the overseas investment management system}

Before 2000, the approval system dominated all types of investment. This highly centralised system was born out of the former planned economy. Under this system, the core measures were to 'examine and verify', enabling the government to strictly control all investment activities, which severely limited companies' enthusiasm for OFDI. The management system for overseas investment was also included in this system. With the transition to a market-oriented economy and the development of China's Going Out strategy, it became necessary to reform this system (Zhang 2009).

At the beginning of 2003, five coastal cities and provinces were chosen as the first locations for pilot reforms of the overseas investment management system: Shanghai, Jiangsu, Zhejiang, Shandong and Guangdong. Under the 'Circular about implementing well the overseas investment approval reform pilots' and the 'Reply agreeing to delegate approval powers over non-trade overseas investment to the responsible pilot departments' issued by MOFCOM in 2003, the constraints on companies that were to be allowed to set up subsidiaries overseas were broadened and the application materials required were simplified in the pilot areas. The departments responsible for trade and international economic cooperation in the pilot areas acquired approval powers, and took charge of examining and issuing approval certificates for non-trade companies' overseas investments in 'non-sensitive' countries and regions. Moreover, in April 2003, MOFCOM expanded the scale of the pilots and several new cities and provinces were included in the pilot list. Through the implementation of the pilots, rich experience for the overseas investment management system was accumulated, forming the basis of the formal reform of overseas investment management in 2004.

In 2004, the State Council published the 'Decision on reforming the investment management system', which declared the termination of the approval 
system. The objective of this policy was to implement an authorisation system and a recording system. Under the new system, the strict and complicated 'examine and verify' procedures were abandoned, granting companies more freedom in investment decision-making. The functions of government concentrated on serving, supervising and regulating.

Overseas investments greatly benefited from this reform. Eleven policies were published in 2003 and 2004, which facilitated the transition to the authorisation system for overseas investments and created the current management system.

As a response to the State Council's 'Decision', 'Regulations on authorising initiation of business overseas' and 'Temporary management method for overseas investment projects' were separately published by MOFCOM and the NDRC, respectively, in 2004. These documents decentralised the authorisation power and gave companies more freedom in overseas investment decisions; they also launched the authorisation system in overseas investment. Furthermore, the roles of MOFCOM, the NDRC and the State Council in the authorisation process were clarified. MOFCOM and its provincial branches took charge of authorising ordinary projects (<US $\$ 1$ million), while the NDRC and its provincial branches were responsible for ordinary-sized resources extraction and large foreign exchange projects. Significant-scale resource extraction ( $>$ \$200 million) and large foreign exchange projects ( $>50$ million) were still to be authorised by the State Council.

These documents also simplified application procedures and materials required. The previous project proposal and feasibility reports were replaced with a new overseas investment application form, and the strict verification procedure was abandoned. The time taken for authorisation was also shortened, which made the system more convenient for companies. In 2005, MOFCOM published 'Implementation rules for the authorisation system for operating a business overseas', in which a new authorisation certificate replaced the old approval certificate for permission to engage in overseas investment. To facilitate investments by central government enterprises, the NDRC launched a recording system in 2007 that gave these SOEs decision-making powers over regular investments valued at less than $\$ 10$ million and for resource extraction projects valued at less than $\$ 30$ million.

In 2009, MOFCOM published the 'Management method for overseas investment'. This document redefined overseas investments, greatly simplified the authorisation procedure and materials and gave companies more decision-making power. The main content is as follows.

- State-owned companies managed by thte central government must apply to MOFCOM for authorisation, and local companies must apply to the local branches of MOFCOM.

- MOFCOM is responsible for authorising investments by central government SOEs; authorising investment in special destinations or in destinations without diplomatic relations; authorisations for countries or regions with investment stock valued at more than US $\$ 100$ million and investments related to certain countries, and projects with special goals.

- The local branches of MOFCOM are responsible for projects ranging in value from $\$ 10$ million to $\$ 100$ million, and for mining and energy investment and projects requiring domestic financing.

- The application materials required include: an investment application; a business licence; contract and bylaws; the authorisation certification from the related departments; and a reporting form for merger activities. Other investments can be approved by MOFCOM (for centrally managed companies) and its local branches (for other companies) by submitting an application form only.

\section{Reform of the foreign exchange management system}

From 2002, China began to reform its foreign exchange management system in 4 respects: simplifying procedures, relaxing controls, launching pilots and providing support. In 2002, SAFE approved 14 cities and provinces as foreign exchange pilots for overseas investment. The main measures included:

- giving pilot regions an annual quota for purchasing foreign exchange to help ease companies' financing problems; 
- treating companies of different ownership types (e.g. SOE, private and foreign funded) equally, so that all types of companies could benefit from the same foreign exchange management system;

- cancelling the risk review procedure for overseas investments and simplifying the procedures for reviewing sources of foreign exchange;

- cancelling the profit margin system and allowing and encouraging companies to make use of profits for expansion or reinvestment; and

- broadening the scope of approval by responsible departments in the foreign exchange reform pilots.

In 2005 , these measures were extended to apply to the whole country.

In 2002, based on the State Council decision to cancel administrative approval of projects, SAFE cancelled the risk review system and profit deposit regulation for overseas investments. In 2003, the procedure for examining foreign exchange sources was simplified through the 'Circular on simplified examination of foreign exchange sources'. In 2006, the foreign exchange quota was cancelled in the 'Circular on adjusting some foreign exchange policies'. All of these policies increased the convenience for companies and helped boost overseas investment.

In 2009, a systematic overseas investment foreign exchange policy was published in 'Management regulations for domestic companies to make overseas investments'. This document summarised the reforms in recent years and further simplified the foreign exchange procedures. This policy removed the requirement for an early-stage review; companies needed only to lodge a record with SAFE when making transfers of foreign exchange. The main materials to be recorded include: an application; a statement about the foreign exchange sources; the business licence or the organisation registration code; the investment permission; and a certificate of transfer of foreign exchange in the earlier stages of the project.

\section{Reform of finance, credit and taxation policies}

The establishment of China's Going Out strategy was accompanied by the creation of several funds to support overseas investments by Chinese companies. A variety of Chinese financial institutions and taxation policies played important roles in funding overseas investments by companies.

\subsection{Government special funds}

Resource investment fund. China has been concerned with resource investment since the beginning of the Going Out strategy and has issued policies to assist companies in exploring and extracting resources overseas. In 2004, to encourage and support companies engaging in overseas resource investment and to make use of overseas resources to develop economic and technical cooperation, MOF and MOFCOM jointly published 'On implementing well funding for pre-project costs of overseas resources investment and economic and technical cooperation'. In this policy, which emphasised large- and medium-scale resources and economic and technical cooperation projects, China's government allotted special funds to reimburse companies' pre-investment costs. Eligible projects included oil resources and non-metal and metal resources. In 2005, a supplementary circular to this policy was published, which expanded the scope of eligible projects and simplified the funding application procedure.

\section{Special fund for overseas mining resources risk} surveys. To encourage and guide geological survey companies and organisations in exploring mining resources overseas (excluding oil and natural gas), MOF published the 'Temporary method for overseas mining resources risk surveys', which gave priority to funding mining survey projects with good prospects, large reserves and high expected returns. The 'method' mainly focuses on assessing economic benefits and does not require assessment of social and environmental factors.

\section{Outward economy and technology cooperation} special fund. To encourage companies with comparative advantages to develop outward economic and technical cooperation, MOFCOM and MOF jointly published the 'Management method for the outward economy and technology cooperation special fund', which supports companies engaging in overseas investments, overseas agriculture, forestry and fishing cooperation, outward 
project contracting, outward labour services, overseas high-tech research and development, and outward design and consultation, by way of providing direct funding and subsidising the interest on credit.

\subsection{Credit support}

EXIM Bank. In 2003, the NDRC and China's export and import credit institution, EXIM Bank, published the 'Circular on prior support to significant overseas investments'. Through this policy, the NDRC and EXIM Bank established a credit system for overseas investments. The policy stipulated that EXIM Bank would take every year a certain amount of money from the export crediting plan to support 'significant overseas investments'. Significant investments mainly include 'overseas exploration projects for resources that are in domestic shortage; overseas manufacture and infrastructure projects that can stimulate exports of domestic technology, products, equipment and labour services; overseas research and development centre projects that can make use of international advanced technologies, management experience and intellectual property resources; and overseas merger and acquisition projects that can enhance international competitiveness and expand international markets' for Chinese companies.

With the transition from the approval system to the authorisation system, in 2004 this policy was adjusted to make procedures more convenient for overseas investment companies. In 2005, to encourage private companies to make overseas investments, MOFCOM and EXIM Bank published the 'Circular on implementing the import and export privilege credit insurance to support individual and private companies to develop international markets', which made accessing support more convenient for small and private companies.

China Development Bank. In 2005, China Development Bank (CDB) and the NDRC published the 'Circular on strengthening financial support to significant overseas projects'. Through this policy, CDB and the NDRC developed a finance support plan for significant overseas projects every year. Under the plan, $\mathrm{CDB}$ arranges a credit quota from its stock capital to improve its ability to fund support to significant overseas investment projects. It also provides related services to the projects.
China-Africa Development Fund. In November 2006, at the Beijing Summit of the Forum on China-Africa Cooperation (FOCAC), President $\mathrm{Hu}$ Jintao announced that China would undertake eight measures to forge a new strategic partnership with Africa. The third of these measures was to establish a China-Africa Development Fund, to eventually reach capitalisation of US $\$ 5$ billion, with the aim of encouraging and supporting Chinese enterprises to invest in Africa. In March 2007, the Chinese government officially approved the establishment of the China-Africa Development Fund (CADFund), with first-phase funding provided by CDB.

According to media reports, by 2010 CADFund had made $\$ 4$ billion in investments in 35 projects.

Fund characteristics. The aims of CADFund are to promote economic cooperation between China and Africa and to advance Africa's economic development. By investing directly in Chinese enterprises that have set up operations in Africa or plan to invest in Africa, CADFund seeks to support Chinese and African enterprises in achieving their cooperation targets and facilitate infrastructure construction, as well as enhancing social and economic development of African countries. CADFund invests in Chinese enterprises whose trade and economic activities have reached or will reach Africa, and in enterprises and projects in Africa in which Chinese enterprises have invested or will invest. CADFund works differently from economic aid to Africa in that it is not allocated by the recipient nation but is independently operated and disbursed to companies. CADFund invests in projects and requires investment returns. CADFund also differs from credit in that it invests together with enterprises in projects and takes on part of the risk, thus lowering companies' risk; in this way, CADFund will not increase African countries' debt. CADFund aims at promoting China-Africa ties, so it requires that all of its investments and investment targets comply with and conform to laws, statutes, regulations, environmental protection policies and social development policies both of China and of the investment host countries in Africa.

Investment approaches. CADFund provides equity investment, but in principle it would not take a majority stake. CADFund also makes other forms of quasi-equity investments (e.g. preferred stock, hybrid capital instruments, convertible bonds) and investments in other funds that invest in Africa. 
Management mechanisms. CADFund is independently operated based on market economy principles. It assumes sole responsibility for its profits or losses and carries its own risk. Under its standard corporate governance structure, CADFund appoints specialised staff for its management, while also benefiting from the 'going global' experience of staff at CDB. CADFund also provides management, consulting and financial advisory services for Chinese enterprises.

Target group. CADFund's target group consists primarily of Chinese enterprises whose trade and economic activities have reached or will reach Africa as well as the enterprises and projects in Africa in which Chinese enterprises are investing or will invest. An African enterprise can identify a Chinese partner, and the Chinese partner then applies to CADFund. CADFund's website lists the following sectors as key focus points: agriculture and manufacturing infrastructure, natural resources (e.g. oil, gas, minerals) and industrial parks.

EXIM Bank and CDB are important financial institutions in funding overseas investments not only in significant projects but also in a number of smallscale investments.

\subsection{Taxation policies}

The first OFDI-related taxation policy can be traced back to the 'Temporary method for implementing overseas profit taxation' issued in 1995, which defined tax exemption and reduction methods for overseas investments. With the development of China's Going Out strategy, the State Administration of Taxation (SAT) improved the overseas taxation management system to support companies making overseas investments.

In 2007, SAT published the 'Opinion on implementing well taxation services and management of overseas companies', which regulated taxation management for Chinese overseas companies in five areas.

Furthermore, since 1983, China has signed taxation agreements or avoided dual levying agreements with more than 100 countries, which reduces the burden on overseas companies and supports them in making investments.
Investment agreements. By 2007, China had signed bilateral and multilateral investment agreements with more than 110 countries, thus helping to create a favourable environment for Chinese companies investing overseas. These agreements include: China-ASEAN free trade agreement (2002); ChinaPakistan Free Trade Agreement (2003), China-Chile Free Trade Agreement (2005), Asia-Pacific Trade Agreement (2005), China-New Zealand Free Trade Agreement (2008), China-Singapore Free Trade Agreement (2008) and China-Peru Free Trade Agreement (2009). At the China-Africa Forum in 2006, China expressed its willingness to develop free trade agreements with countries in Africa 'when conditions are ripe'.

The content of each agreement depends on the demands and specific conditions of each party to the agreement. The main function of the agreements is to promote trade between economic bodies. Except for the agreement with Peru, in which Article 162 requires China to support studies, training and activities to promote sustainable forest management, no agreement specifically mentions conditions related to forestry. ${ }^{5}$

Information services. MOFCOM provides information services to facilitate companies in Going Out. In 2003, an Investment Promotion Business Bureau was established under MOFCOM and an investment plan information database was launched on MOFCOM's official website, which provides an information and communication platform for overseas and domestic companies and organisations. In 2006, the 'Temporary method for complaints by Chinese overseas companies' was issued and the 'China companies overseas business complaints service centre' was set up in Beijing under MOFCOM, to be responsible for providing free complaint resolution services.

\footnotetext{
5 The China-Peru Free Trade Agreement was written immediately after the US-Peru Free Trade Agreement, which included a long section relevant to trade in forest products and requiring Peru to abide by strict legality standards, especially in relation to timber exports to the United States. The Chinese agreement, while significant in that it contains a section on forestry, promises some support to Peru's forestry sector, especially in terms of providing research on sustainable forest management, but has few clear binding requirements, unlike the US agreement (see e.g. Putzel 2009).
} 
Investing country guidance. To support companies' overseas investments and enhance the potential for companies to benefit from OFDI, MOFCOM has developed a series of guidance documents. Some outline recipient countries' investment environments, such as the 'Country trade and investment environment report' in 2003 and 'Country (region) guide for outward investment and cooperation' in 2004. They provide a large amount of information on investment- and trade-related laws and regulations, taxation policies, market conditions and industry opportunities for Chinese companies. They also describe common problems encountered in overseas investments in those countries and regions. Some guidance documents list the sectors that are encouraged by the recipient countries, such as 'Country industry guidance index for overseas investment' in 2003 and 'Overseas processing trade country guide' in 2004 . These information services cover almost all countries worldwide and help to reduce search costs and investment risks for Chinese companies. The guidance documents also address the environmental and social dimensions of investment, particularly in the 'Country trade and investment environment report' and the 'Country (region) guide for outward investment and cooperation'. For example, the 'Country (region) guide' for the Democratic Republic of Congo outlines that country's environmental laws and provides tips for establishing good relationships with the recipient country (see Box 1).
Professional training measures To address the lack of trained staff, MOFCOM initiated the 'Transnational operation talents training plan' in 2007 and published the 'Textbook for management talent in transnational operations' in 2009. The training and textbooks help support the development of trained staff for Chinese companies investing overseas.

\subsection{Supervision and regulatory measures}

Along with issuing supportive policies, China also strengthened management and regulation of companies investing overseas. Especially since 2005, many problems have emerged because of the sharp increase in the number of overseas investment companies.

Improving the outward investment statistics system Although the 'Opinion on the National Planning Commission reinforcing control of overseas investment projects' of the State Council in 1991 specified that the National Statistics Bureau (NBS) was in charge of statistics on overseas investment in China and should report regularly to the State Council, no official public report was published between 1991 and 2001. In 2002, NBS together with MOFTEC developed and issued the 'Outward investment statistics system', was wassubsequently revised in 2004, 2006 and 2008. In 2006, MOFCOM collaborated with Chinese overseas

\section{Box 1. Extract from MOFCOM's country guide on DR Congo}

\subsection{Environment laws}

\subsubsection{Environmental protection administrative agencies}

The Environment Ministry of DRC is the main administrative agency for environmental protection, and its main responsibility is to motivate and coordinate activities related to the environment.

\subsubsection{Main environmental laws and regulations}

- Forest Code, issued 29 August 2002

- The Act for Organising the Exploitation and Exportation of Fisheries, issued 18 February 1994

- Mining Act, issued 11 July 2002

- Investment Act, issued 21 February 2002

- No. 005/CAAB/MIN/ENV/2005 and 107/CAAB/MIN/FINANCES/2005, which require payment of environmental taxes

\subsubsection{Key points on environment laws and regulations in DRC}

Investors must conduct an environmental impact assessment (EIA) before investing, and enterprises are obliged to mitigate negative impacts on the local environment. Companies will be subject to punishments by the government if they generate any harm caused by inappropriate activity. The standard for EIAs in DRC is mainly based on the standard and methods of the World Bank.

Source: MOFCOM 'Country (region) guide' for DR Congo 
business organisations to establish the 'China foreign direct investment countries (regions) data checking system', which ensures the accuracy of China OFDI data through cross-checking of domestic and overseas data.

The definitions, statistical rules and calculation methods for China's outward investment statistics system are now based on the OECD's 'Benchmark definition of foreign direct investment' and the IMF's 'Balance of payments manual (5th edition)', and thus provide comprehensive, comparable and timely data on Chinese overseas investment. MOFCOM, SAFE and NBS distribute an annual OFDI bulletin as an internal document, but this is not publicly available, which is why related scientific publications are rare.

\section{Establishing a merger management system.}

Realising that mergers and acquisitions were becoming an important investment approach, MOFCOM published the 'Early-stage reporting system for overseas mergers', which required companies to make timely reports about their merger decisions to MOFCOM and SAFE or their provincial branches. In 2009, the NDRC issued the 'Circular on improving overseas project management', which required companies to forward merger project information and copies to the related responsible departments before initiating the merger. This system of merger management was also reflected in the 'Management method for overseas investment', which states that the merger report is a necessary application document to be supplied when applying for authorisation.

\section{Company registration. In 2005, MOFCOM}

initiated a registration system for Chinese companies investing overseas. Under this system, companies with overseas investment permission from MOFCOM and its provincial departments are required to register at the business department of the Chinese embassy in the investment destination.

\section{Performance appraisal and annual inspection joint} system. To supervise the activities of companies overseas, MOFTEC issued the 'Overseas investment integrated performance appraisal method (temporary)' and the 'Temporary method for annual inspection of overseas investments' in 2002. The first document aims to evaluate the performance of Chinese overseas investment companies against five criteria - profit, solvency, asset quality, development capability and social contribution to China - and applies 17 financial indexes to reflect the profit conditions of overseas investment companies. The second document focuses on strengthening the supervision of overseas investments at the macro level. Enterprises are given an evaluation score, and companies deemed not to pass the evaluation are deprived of their concessionary benefits, such as credit and special fund support. Based on this, MOFCOM and SAFE began making joint evaluations and inspections of companies' investment conditions and their compliance with Chinese domestic laws for eight years from 2003, to supervise and regulate the activities of companies with the aim of improving the Chinese government's profit control capability.

In 2009, MOFCOM and SAFE adjusted these policies. Recipient countries' issues were also considered important factors in evaluating performance, and this factor now accounts for $20 \%$ of the whole score given. Ten per cent of points are deducted if a company violates local laws and is penalised by the recipient country. The same percentage of points is also deducted for any quality, safety, environmental or labour problems or conflicts.

Regulating the activities of companies. In 2008, because of increases in labour and business conflicts, environmental protection concerns and project quality problems, MOFCOM, the Ministry of Foreign Affairs (MFA) and SASAC jointly published the 'Circular to regulate the overseas investment and cooperation of Chinese companies'. Companies that violate laws and regulations and cause serious incidents in the recipient country are penalised by MOFCOM, MFA and SASAC. The 'Management measures of overseas investment' of 2009 again addressed regulation of companies' activities, requiring companies to comply with the laws and regulations of investment destinations and to consider social responsibility when conducting their business affairs.

'Green finance' regulatory measures. China’s financial regulatory agencies have also been promoting various regulatory measures under the rubric of 'green finance'. Originally designed to address the environmental impacts of domestic investments, a system is taking shape whereby credit providers (e.g. banks) are encouraged to develop measures to restrict 
credit for polluting or otherwise environmentally damaging industries, and give credit preference to green and environmentally friendly industries. Banks have developed different systems for putting this into practice, or are in the process of developing such systems. Investment project approval is also subject to an environmental impact assessment (EIA) process. The banking system regulatory agencies are supposed to have oversight over these systems, and these systems are supposed to apply for credit from Chinese banks for overseas investment projects.

The first 'green finance' policy dates back to 1995, when the PBC published the 'Circular on implementation of credit policy and enforcement of environmental protection' and required the banking system at each administrative level to consider natural resources and environmental protection when extending loans. Implementation did not begin until 2006, after the State Council issued a document 'On implementing the scientific outlook on development to strengthen environmental protection' in December 2005. This policy required banks to withdraw credit from companies that do not meet the national industry policy and environmental standards (Zhou and Chen 2007). Under this framework, and considering the role of financial institutions in promoting environmental protection, in 2006 the Ministry of Environmental Protection (MEP), the PBC and the China Banking Regulatory Commission (CBRC) began to publish policies to implement 'green finance'.

\section{In December 2006, the MEP (then named State} Environmental Protection Administration, SEPA) in conjunction with the PBC published the 'Circular on sharing information on corporate environmental issues'. This policy imported environmental information on companies into the Basic Company Credit Database that is used by banks and the financial regulatory agencies in credit application reviews, and laid the foundations for 'green finance'. Based on this, in July 2007, the MEP, PBC and CBRC published the 'Opinion on implementing environmental protection policies to prevent credit risk, which required banks to control provision of credit to unqualified companies and companies that violated environmental laws. It suggested 'making use of credit measures to protect the environment'. This was the first multi-agency policy to limit the unruly expansion of high energy-consuming and polluting companies, and marked the establishment of China's 'green finance' concept (Yu 2009). Around the same time, the CBRC published 'Guide on energysaving credit work' and the 'Circular on carrying out the macro-control policy to regulate loans to high energy-consuming and polluting companies', which required the banking system and financial departments to combine credit structure adjustments with national economy structural adjustments in order to prevent credit risk and to implement the energy-saving and environmental protection policies (Ge et al. 2010).

In November 2007, the CBRC issued the 'Opinion on strengthening the social responsibility of financial institutions', which required the large banks to fulfil their social responsibility obligations by adhering to the 10 principles of the UN Global Compact. In January 2008, the former SEPA and the International Finance Corporation signed a cooperation agreement to develop credit guidelines in accordance with the Chinese situation in order to deepen the implementation of 'green credit'. In January 2009, the China Banking Association (CBA), an industry association, published 'China banking system and financial departments' corporate social responsibility guidelines', which stressed the need for the banking system to meet its social responsibility requirements and to support the sustainable development of the environment, economy and society.

The opportunities provided by 'green finance' initiatives aroused considerable concern in the government, which is now actively developing a role in regulating the activities of enterprises through control of credit. Especially since 2005, the government has issued several important policies. Some international finance practices were also included in the 'green finance' system, and Chinese banks have begun to consider environmental information as an important aspect in their credit and loan practices. The implementation of green finance in practice has been much more varied among financial institutions. However, as an example, the following summarises the environmental policies and practices of the two main credit players in China overseas investment.

\section{Export-Import Bank of China (EXIM Bank).}

The 'Guidelines for environmental and social impact assessment of the China Export and Import 
Bank's (China EXIM Bank) loan projects' issued in August 2008 outlined its environmental and social responsibility requirements in relation to credit loans. At the core of the guidelines are three main activities: prior review, process oversight and post review.

Prior review: An EIA and a social impact assessment (SIA) are required for loan applications. EXIM Bank reviews the loan application, including the EIA and SIA submitted by the borrower, which must also get approval from the relevant national authorities in the recipient country. Independent experts are to be hired if necessary to review these documents. EXIM Bank then negotiates with the borrower to amend the project proposal, based on the environmental and social assessment. In EXIM Bank's rubric, 'EIA' refers to the systematic analysis and evaluation of environmental impacts and their related impacts on human health and safety due to the implementation of a project, and suggestions for reducing the impact. The scope of impact assessment includes air, water, soil, waste, natural environment and other factors. 'SIA' refers to the systematic analysis and assessment of the impact on socio-economic, natural resources and social environment caused by project implementation, and suggestions for reducing that impact. The scope of evaluation includes labour and terms of employment, social security and health, land acquisition and migrants' protection.

Process oversight. EXIM Bank inspects environmental and social impacts of the project. The borrower must make regular reports on the project's environmental and social impacts, as well as the measures adopted to eliminate or control these impacts.

Post review. When the project is completed, a post review is conducted to appraise all the operating conditions as a reference for other similar projects. The borrower must submit to EXIM Bank environmental documents for completion of the project. These documents must meet the requirements of the recipient country.

China Development Bank (CDB). To promote energy saving, social responsibility and environmentally sound lending, CDB published the 'Guidance of China Development Bank on reviewing the development of environmental projects' and 'China Development Bank pollution-reducing and energysaving work plan' (Ge et al. 2010). In addition, as part of the implementation of a World Bank loan project, $\mathrm{CDB}$ issued the 'EIA framework for small business loans projects', which referred to the World Bank's EIA policy (OPA.01) and related Chinese laws and regulations. Since 2006, CDB has been committed to adhering to the UN Global Compact. CDB's responsible credit policies include 3 parts: qualification examination, prior review and process oversight. In the qualification review, the applicant's record regarding legal violations and its compliance with related environmental laws and policies are examined. In the prior review phase, the expected benefits, including the resource and environmental costs, are considered. In the process oversight, $\mathrm{CDB}$ consults local environmental agencies to check the operation of the sponsored project to ensure it fulfils the related environmental protection requirements. In addition, CDB's guidelines have incorporated some international environmental and social practices, such as respecting local customs and labour laws and regulations (Ge et al. 2010).

\section{Discussion}

This paper has summarised the overseas investment policy system in China, a system that has undergone major transitions in the past 30 years. At the beginning of the 'reform and opening up' period, initial attempts to undertake overseas investment helped to lay the foundations for China's OFDI management system. In the outward foreign tradeoriented period of the 1990s, restrictive policies limited the development of OFDI to some degree. With the advance of the wider reform process, and the concomitant adjustments to the economy, a strategy of prioritising support for overseas investment was ultimately established. The recent and current policy environment has proved to be supportive of OFDI, and Chinese OFDI has attracted global attention. At the same time, a new trend of strengthening the responsibility of companies operating overseas has emerged, with several policies supporting this trend published in recent years. Examples include the 'Performance appraisal and annual inspection joint system' of MOFCOM, the 'Overseas forestry sustainable management guideline for Chinese enterprises' (State Forestry Administration) and various initiatives related to 'green finance' in the Chinese finance and banking system. Although some of 
these policies take the form of voluntary guidelines and 'suggestive' policies (meaning they lack a basis for legal enforcement), the fact that they were issued shows how the Chinese government's attitude has shifted towards an approach that considers both economic benefits and social and environmental responsibility. Chinese nongovernmental organisations and international nongovernmental organisations operating in China have also launched some initiatives to support the development of these policies through their advocacy work.

The Chinese government's approach to OFDI is encapsulated in the Going Out strategy, which the minister of MOFCOM has noted will remain a key feature in the Chinese $12^{\text {th }}$ Five Year Plan period, when we can expect more measures to be taken to support overseas investment. At the same time, we can expect that more policies concerning the social and environmental impacts of Chinese OFDI will be issued, supplementing China’s existing OFDI management system.

From the perspective of research concerning the potential impact of Chinese overseas investment on natural resources in host countries, this review suggests the following as potential future research areas.

1. Enhancing understanding of China's overseas investment policy system, including research on:

- policy responses in the context of the international financial crisis;

- policy adjustments in response to failures in overseas investment by Chinese companies; and

- processes in policy responses to international initiatives and overseas practices regarding environmental and social safeguards and standards.

2. Enhancing understanding of the monitoring, supervision and feedback mechanisms within the Chinese system, and their implementation in practice, such as:

- the process and conduct of 'joint inspection' missions involving MOFCOM;

- the implementation of environmental and social safeguard policies within the banking system; and
- the ways in which safeguard policies are addressed and implemented by Chinese stateowned, state-regulated and purely private companies.

Better understanding of the processes, frameworks and protocols applied in these areas, and experience with their implementation in practice, would enhance understanding of the links between China's OFDI activities and the formulation and adjustment of related national policies.

\section{References}

Central People's Government 2010 Individual and private companies made a great achievement on social and economic benefit in the period of the 11th five years (31 December). http://www.gov. cn/gzdt/2010-12/31/content_1776516.htm [13 October 2011].

Chen, S.F. 2009 China OFDI policy system research. Shen Yang Industrial University, Shen Yang (in Chinese).

CCPIT 2007 Analysis of incubation for China's 'Going Out' strategy and its promotional policies. CCPIT, Beijing, China (in Chinese).

Clarke, D.C. 2003 Corporate governance in China: an overview. China Economic Review 14: 494-507.

Deng, B. 2003 Discussion of family management system among private companies in China. Enterprise Economy 12: 38-40 (in Chinese).

Fang, Z. 1999 China's economy under the Southeast Asian Financial Crisis. China Review, Hong Kong.

Ge, C.Z., Xia, Y.F., Zhi, Y.B. and Long, F. 2010 Environmental policies for China's overseas investments. China Environment Science Press, Beijing, China (in Chinese).

Liao, T.L. 2009 Discussion on the information disclosure system of China's security market. Commercial Culture 6: 60 (in Chinese).

Lin, G. and Schramm, R.M. 2003 China's foreign exchange policies since 1979: a review of developments and an assessment. China Economic Review 14: 246-280.

Lu, G. 2002 Reform of the administrative approval system to boost the sound development of OFDI. Review of Economic Research 66: 18-26 (in Chinese). 
Ministry of Commerce, People's Republic of China (MOFCOM) 2009 China OFDI Statistical Bulletin 2009. MOFCOM, Beijing, China.

Ministry of Commerce, People's Republic of China; National Bureau of Statistics, People's Republic of China; State Administration of Foreign Exchange (MOFCOM, NBS and SAFE) 2009 2009 Statistical Bulletin of China Outward Foreign Investment. Department of Outward Foreign Investment and Economic Cooperation, MOFCOM, Beijing, China.

Mueller, M. and Lovelock, P. 2000 The WTO and China's ban on foreign investment in telecommunication services: a gametheoretic analysis. Telecommunications Policy 24: 731-759.

Munro, S. and Yan, S. 2003 Recent government reorganization in China. China Law and Policy Newsflash, O’Melveny \& Myers LLP, New York.

Naugthon, B. 2006 Top-down control: SASAC and the persistence of state ownership in China. Paper presented at the conference 'China and the World Economy,' Leverhulme Centre for Research on Globalisation and Economic Policy, University of Nottingham, UK, 23 June.

Naughton, B. 2007 The Chinese economy: transitions and growth. MIT Press, Cambridge, MA.

Niu Y.J. 2007 The discussion on types and characteristics of China's private enterprises. Modern Business Trade Industry. 19(12): 87-88.

Pearson, M.M. 2005 The business of governing business in China: institutions and norms of the emerging regulatory state. World Politics 57: 296-322.

Pettis, M. 2005 Buy abroad, benefit at home. Far Eastern Economic Review 168(7): 27-29.

Putzel, L. 2009 Upside-down: global forestry politics reverses direction of ownership in Peru-China timber commodity chains. Paper presented at XIII World Forestry Congress, Buenos Aires, Argentina, 18-23 November. http://www.illegal-logging.info/ uploads/2009LouisPutzelthesupplyoftimberfromPe rutoChina.pdf [13 October 2011].

Schwartz, A.J. 2005 Dealing with exchange rate protectionism. Cato Journal 25: 97-106.

Shan, W. 1989 Reforms of China's foreign trade system. China Economic Review 1: 33-55.
Shi, S. and Gelb, C. 1998 PRC government restructuring continues. China Business Review 25(5): 52.

UNCTAD 2006 World investment report 2006: FDI from developing and transition economies: implications for development. United Nations, New York and Geneva.

Voss, H., Buckley, P. and Cross, A. 2008 Thirty years of Chinese outward foreign direct investment. Conference paper presented at Chinese Economic Association (UK) annual conference. Cambridge, UK, 1-2 April 2008. http://www. ceauk.org.uk/2008-conference-papers/VossBuckley-Cross-30-years-outward-FDI.doc [13 October 2011]

Yang, F. 2010 Discussion on the advantages and disadvantages of the family management system for small and medium companies. Modern Economics 143: 98 (in Chinese).

Yu, X.G. 2009 Environmental report on Chinese banks. Yunnan Science Press, Yunnan, China (in Chinese).

Zhang, L.Q. 2009 Thoughts on China's administrative approval system. Master's thesis, Fudan University, Shanghai, China (in Chinese).

Zhang, Y. 2003 China’s emerging global businesses: political economy and institutional investigations. Palgrave Macmillan, Basingstoke, UK.

Zhang, P.G. (2004) Chinese yuan (Renminbi) derivative products, World Scientific Publishing, Singapore.

Zhao, M. 2006 External liberalization and the evolution of China's exchange system: an empirical approach. World Bank China Office Research Paper No. 4. World Bank, Beijing, China. http://siteresources.worldbank.org/ INTCHIINDGLOECO/Resources/external_ liberalization_and_exchange_control.pdf [13 October 2011].

Zhou, Y.H. and Chen, W.W. 2007 Environment information disclosure of companies and green crediting. Green Accounting 9: 49-52 (in Chinese).

Zweig, D. and Bi, J. 2005 China's global hunt for energy. Foreign Affairs 84(5): 25-38. 


\section{Annex 1. Policies to support privately owned companies in making overseas investments}

\section{Introduction}

There are various ways to categorise Chinese companies according to the type of ownership. Chinese companies take four main forms: stateowned companies, limited liability companies, individually privately owned companies and collective enterprises. Limited liability companies include a variety of enterprises with different sources of funds, including joint investment enterprises and companies that were formerly state-owned enterprises (SOEs) that have been privatised, and companies established by investments from several SOEs or by SOEs together with non-public sources of funding.

Individually owned private companies are an important part of China's economy. According to statistics from the State Administration for Industry and Commerce (SAIC), as of September 2010, China had 34.06 million private companies, providing more than 160 million jobs and accounting for over $90 \%$ of new employment opportunities (Central People's Government website, 31 December 2010).

With the development of China's Going Out strategy, more and more individually privately owned companies have seized this opportunity to make overseas investments. According to the 2009 'Statistical bulletin on China's outward direct investment', individually owned private companies accounted for $7.5 \%$ of all enterprises making overseas investments, which ranks them third behind limited liability companies $(57.7 \%$ of total investors) and SOEs (MOFCOM 2009). In fact, many privately owned companies register as limited liability companies, so the contribution of limited liability companies also includes a large share of private investors. This indicates that the influence of individual and private companies in overseas investment is growing.

When looking back at the development history in China over the past three decades, we can see that the one of the mainstays of Chinese economic reform has been to activate private companies. During the reform process, their role has increased greatly, with them becoming an important component of China's economy as well as often acquiring the confidence and the capability to explore and engage in overseas business opportunities. Policies aiming to encourage individual companies to make overseas investments have also played a part in this development. With the implementation of China's Going Out strategy, several specialised policies were published to support OFDI by private companies.

\section{Characteristics of Chinese individual and private companies}

The particular characteristics of individual and private companies to some extent determine their activities. First, most individual and private companies are small in size, although some have grown rapidly in recent years. This means they are more flexible and can easily adapt to market changes and opportunities. Second, many individual and private companies are market oriented, as their main goal is to maximise profits (Niu 2007). Third, the family management system is a common form of management. Based on kinship relations, this form of relationship among workers can reduce companies' costs and increase labour efficiency because some labour input is free. This provides a competitive edge and enables rapid capital accumulation. In addition, the coherent interest of the whole family can improve the efficiency of decision making and implementation (Yang 2010). Furthermore, most of the owners of these companies experienced tough times in their childhoods, which built up their endurance, meaning that, under their leadership, these companies can survive in harsh environments (Niu 2007).

With the reforms, however, individual and private companies began encountering competitive challenges from both domestic and overseas actors, especially after China joined the World Trade Organization. The Going Out strategy therefore provided them with good market opportunities, especially in markets in developing countries. This 
strategy also gave them support as they pursued overseas investments. In view of the market environment and their characteristics, Going Out became a necessity for many individual and privately owned companies (Zhang 2008).

On the other hand, individual and private companies also experience some constraints in this endeavour. Usually, their market orientation means they tend to pay less attention to investment impacts and social responsibility. This attitude is sometimes reflected in the negative environmental and social records of some companies in overseas investment. The family management system can also hamper efficiency. Reliance on trust within the family may limit the entry of intellectual resources from outside the company, thus potentially creating a bottleneck as companies begin to explore overseas markets (Deng 2003, Yang 2009).

\section{Policies supporting individual and private companies in making overseas investments}

In developing Chinese overseas investment, new regulations issued by MOFCOM in 1985 eased restrictive policies on overseas investment and opened up the approval process to state-owned companies other than trading companies (Zhang 2003). Some researchers even suggested that private enterprises should be allowed to invest abroad (Tan 1999). The political debate on the purpose and usefulness of Chinese overseas investment and on the gradual legitimisation of privately owned firms suggests that the 1985 directive affected state-owned companies only.

After the State Council's directive in 1991, large-scale investment became strictly controlled, but provincial governments gained powers to approve investments valued at less than US $\$ 1$ million. Compared with MOFCOM's 1985 regulations, in which the superior department of the investing organisations was responsible for approving investment proposals, the scope became broadened because such superior departments generally existed only in the SOE management system.

Throughout the 1990s, international trade and cooperation were encouraged and many private companies were awarded licences for import and export. Therefore, private companies also engaged in overseas investments in the overseas processing and assembly business.

Entering into the third phase in the development of Chinese OFDI, the management system reforms encouraged private companies' overseas exploration and explicitly legalised their role. In the pilot project of the approval system and foreign exchange management reform, privately owned enterprises received the same treatment as SOEs. In addition, the State Council's 'Several opinions on encouraging and guiding individual private and non-publicly owned companies' formally expressed the government's attitude in encouraging private companies to engage in overseas investment.

Six months later, MOFCOM and the China Export and Credit Insurance Corporation (Sinosure) jointly published the 'Circular on supporting individual and privately owned companies exploring the overseas market with export credit insurance', which followed up in more detail the attitude expressed in the 'Opinion' of the State Council. In this document, MOFCOM and Sinosure state their aim to give better service to private enterprises as they explore markets and aim to improve profitability, by providing them with insurance to lower the investment risk and make accessing funds more convenient.

Under the influence of the 'Opinion', MOFCOM and the National Association of Industry and Commerce (NAIC) published 'Several opinions on encouraging and supporting non-publicly owned enterprises in making overseas investments' in 2007. This document encouraged privately owned companies to engage in international competition and cooperation through overseas investments, overseas project contracting and overseas labour services cooperation, and stressed that they would have the same benefits as publicly owned companies in terms of authorisation procedures, finance support and information services, among others.

In addition, the recently published 'Management method for overseas investment' further supports private companies and gives them more freedom. In the current overseas investment authorisation system, 
projects valued at less than US $\$ 1$ million can get permission from MOFCOM (central government state-owned companies) and its local branches (other companies) within three days. Furthermore, the application procedure has been greatly simplified. However, under this system, some companies may not be supervised, especially when the investment value is below the authorisation threshold.

\section{Conclusion}

The engagement of private companies in overseas investment has changed during the course of China's reforms. The companies' characteristics and operating environment combine with China's policies to contribute to explaining their increasing role in exploring overseas markets. 


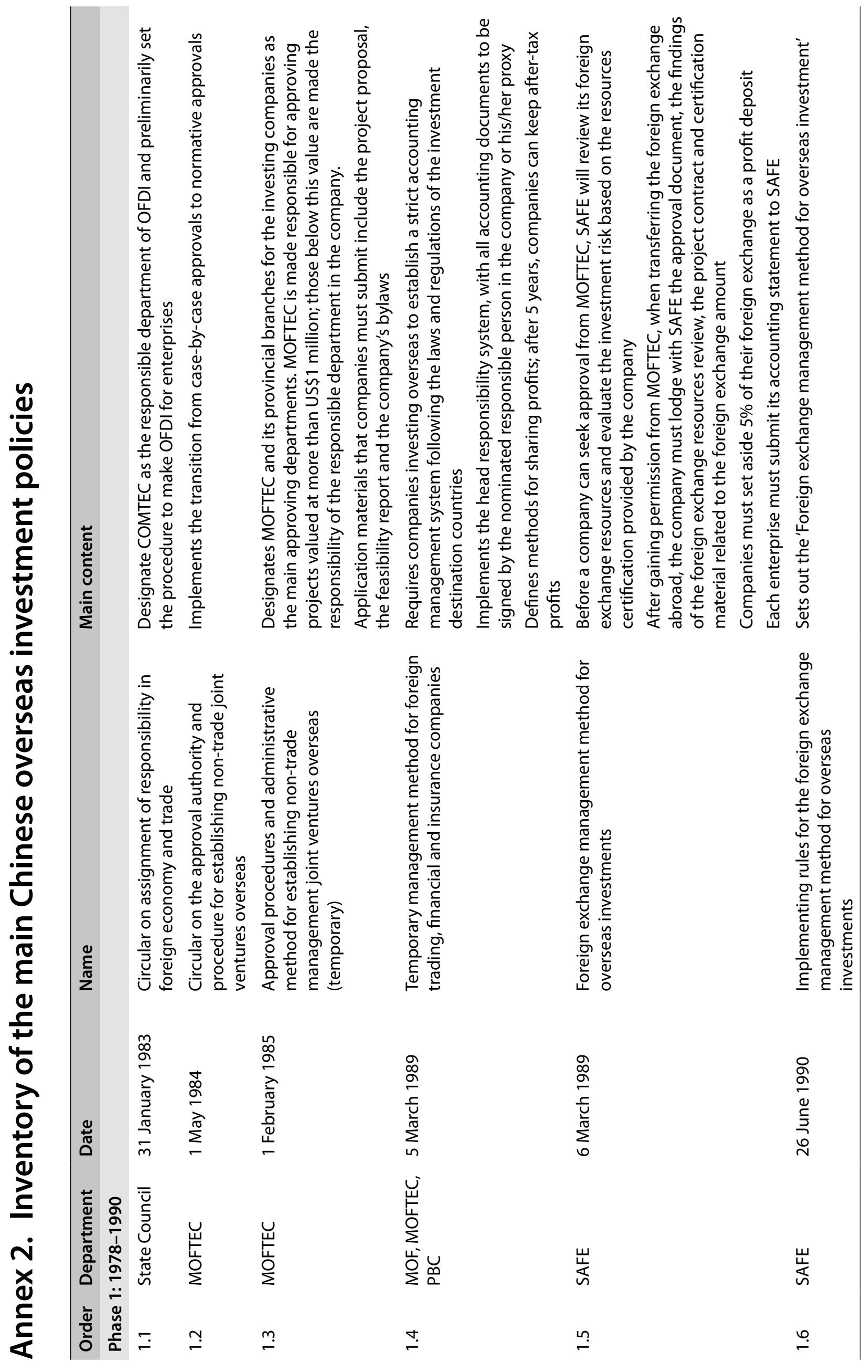




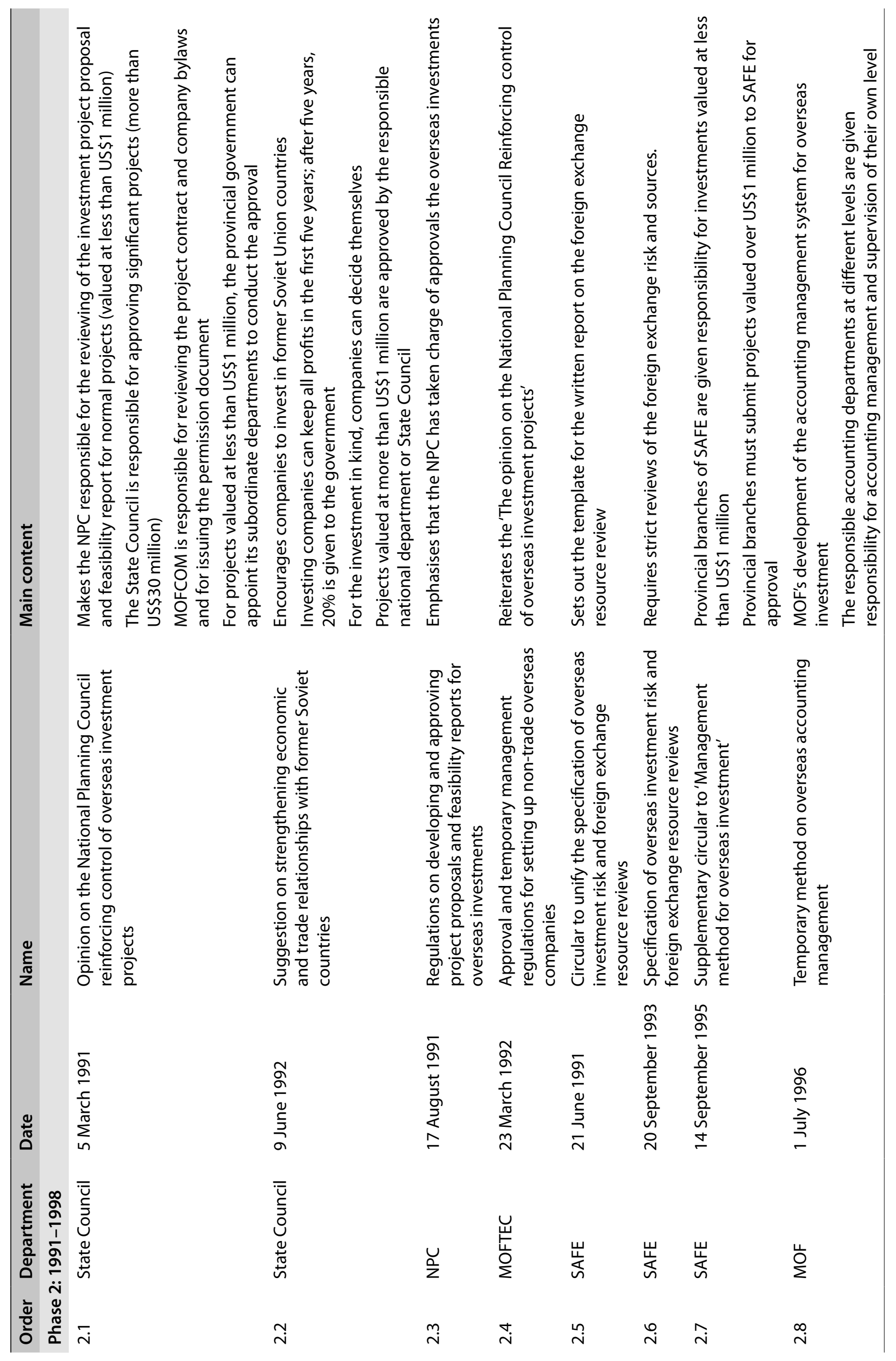




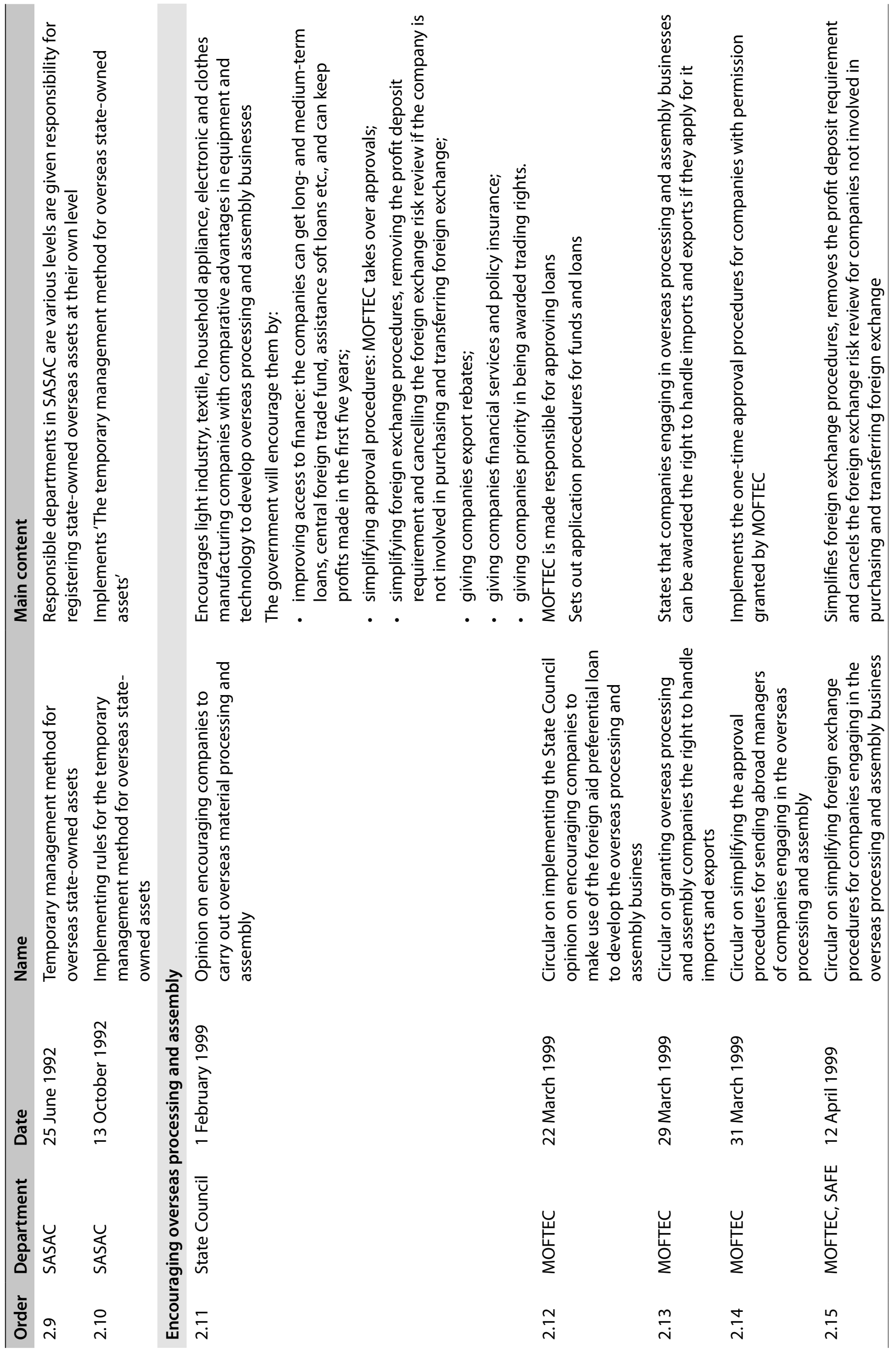




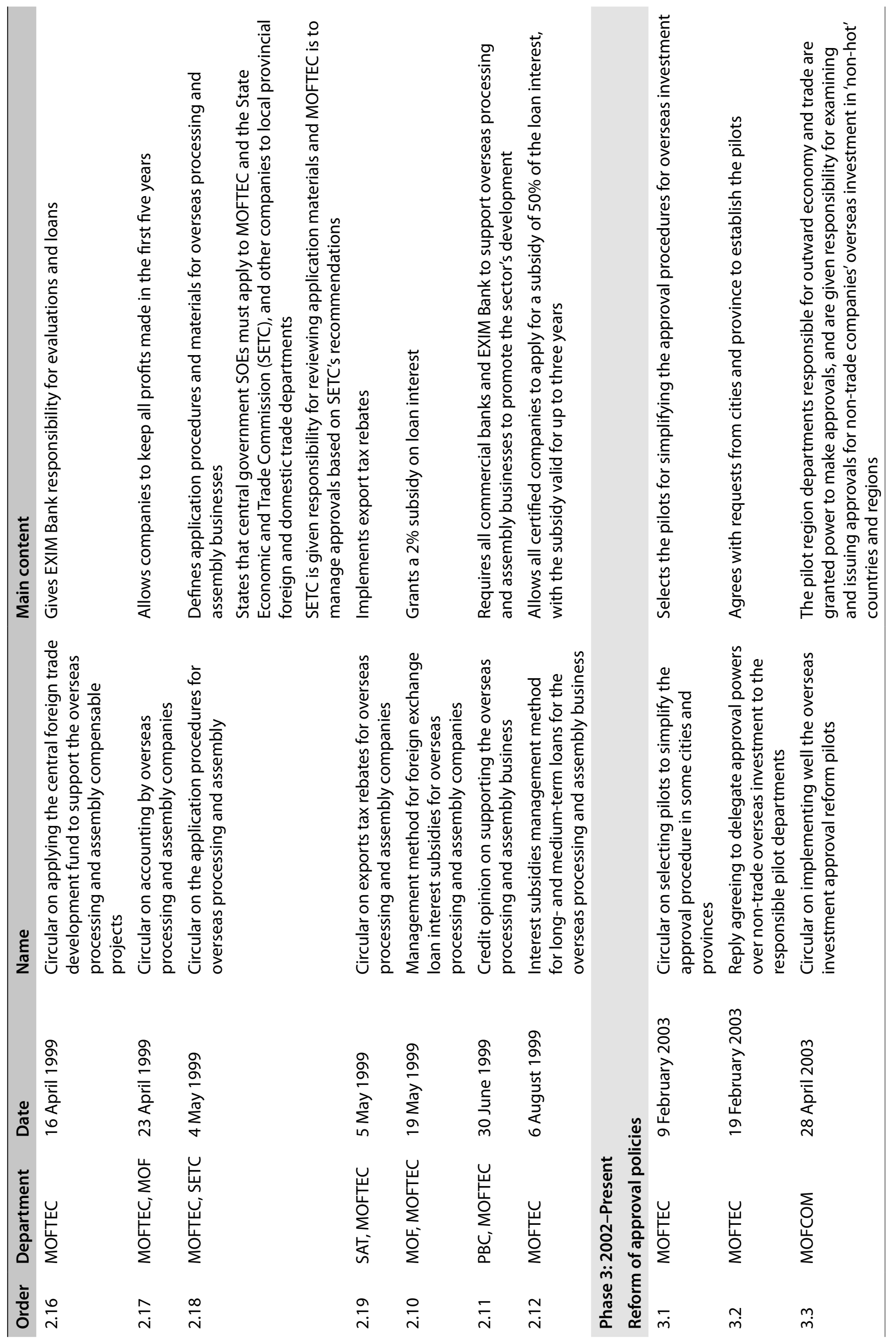




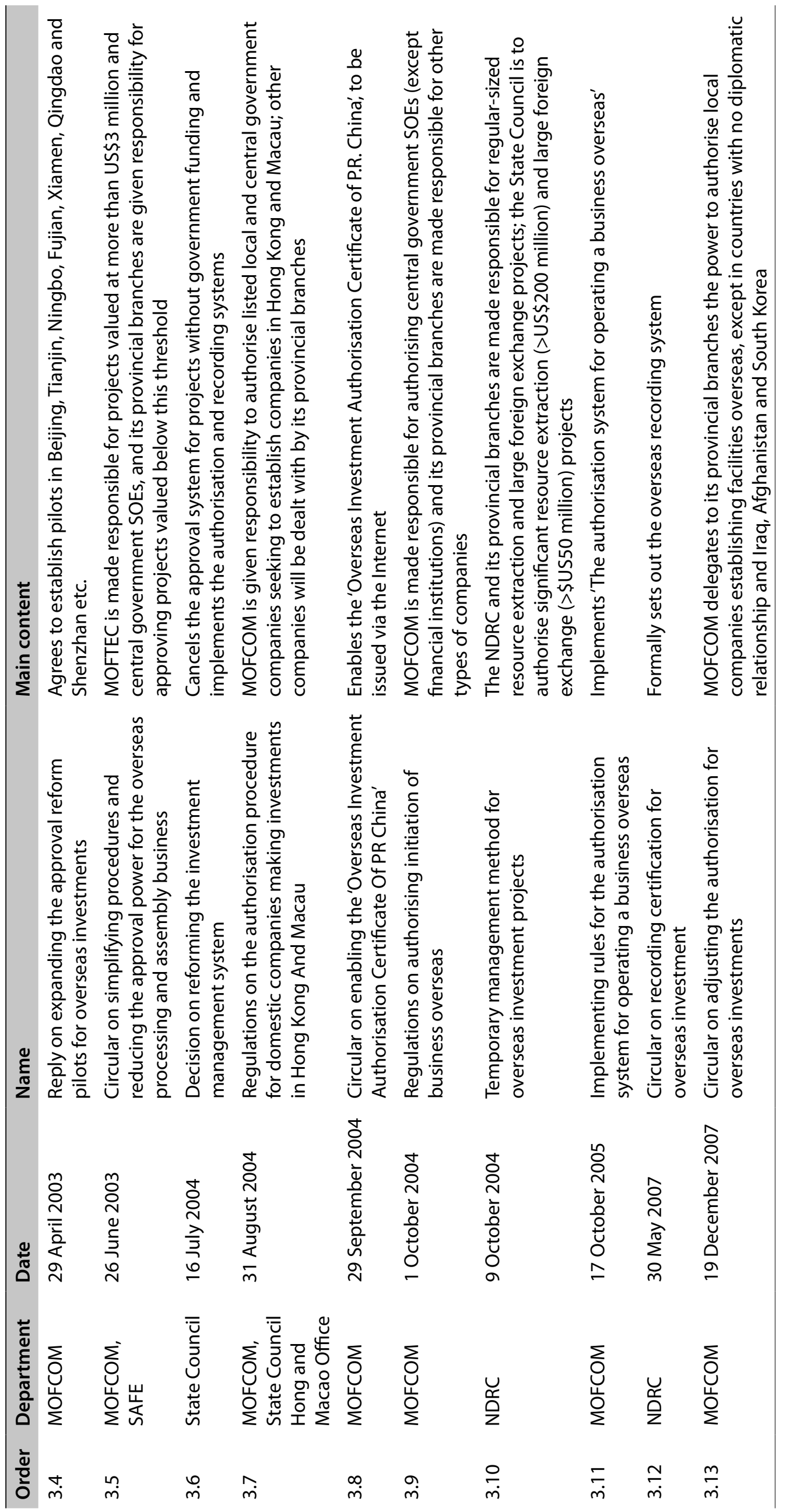




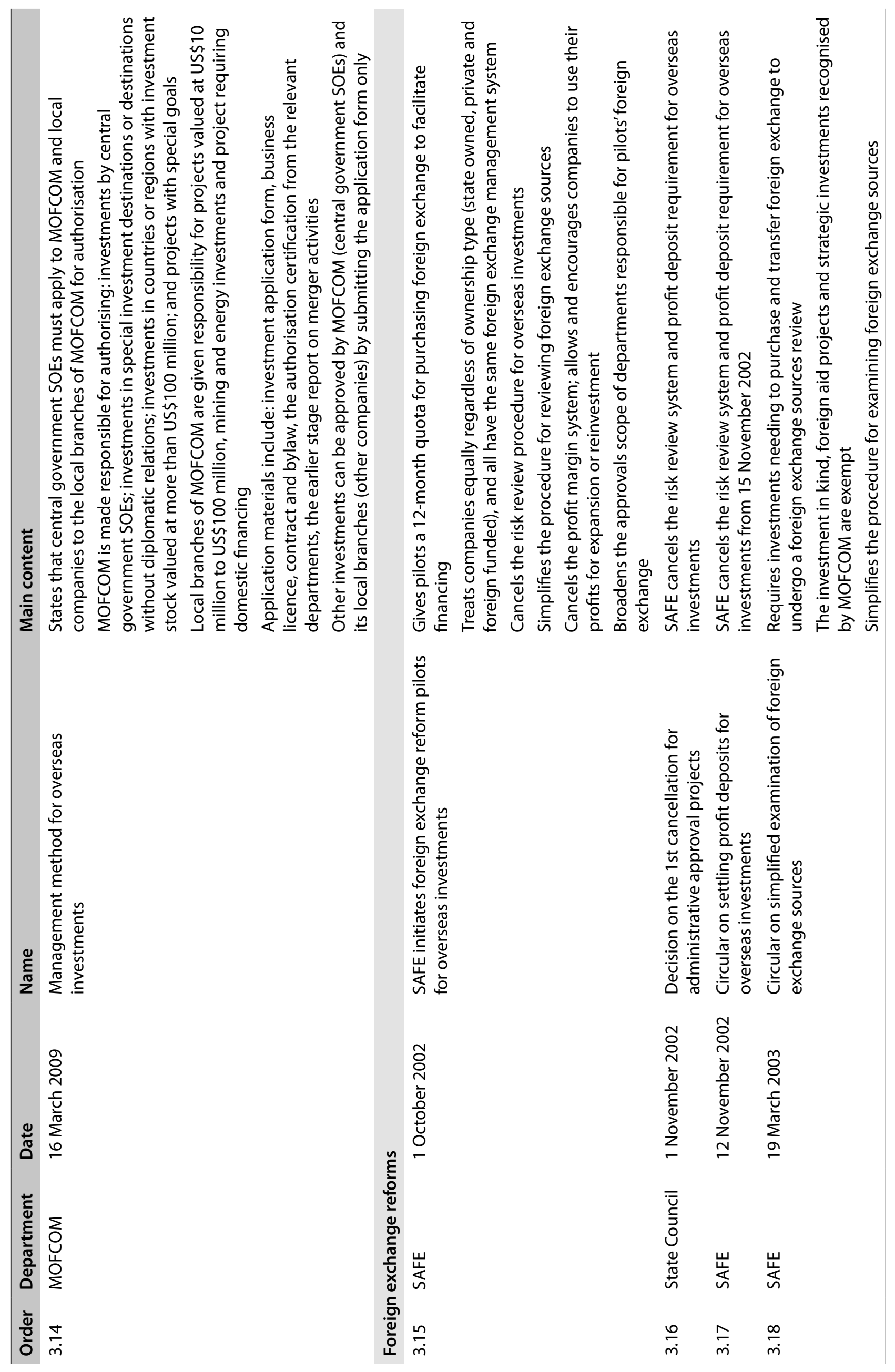




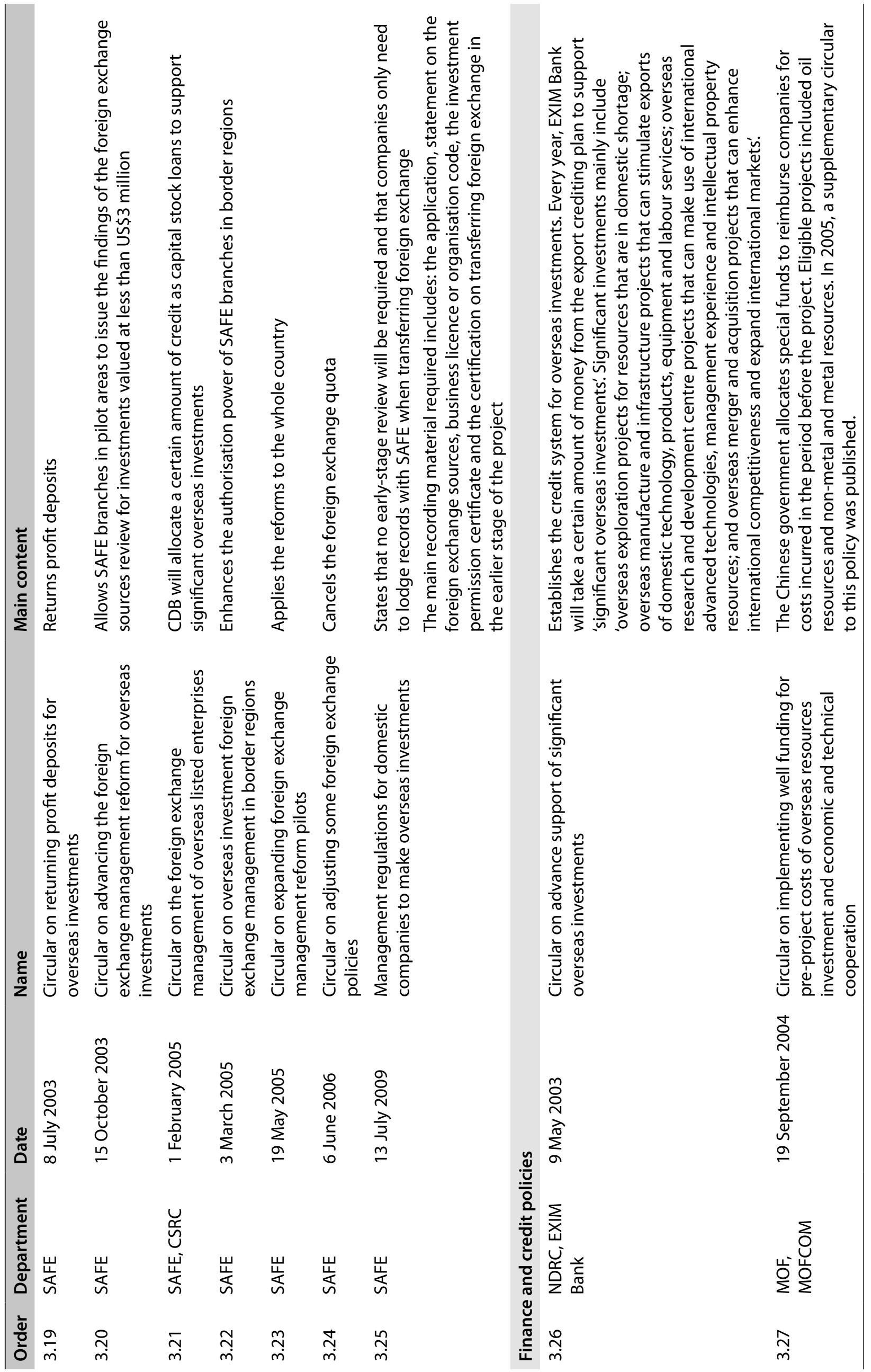




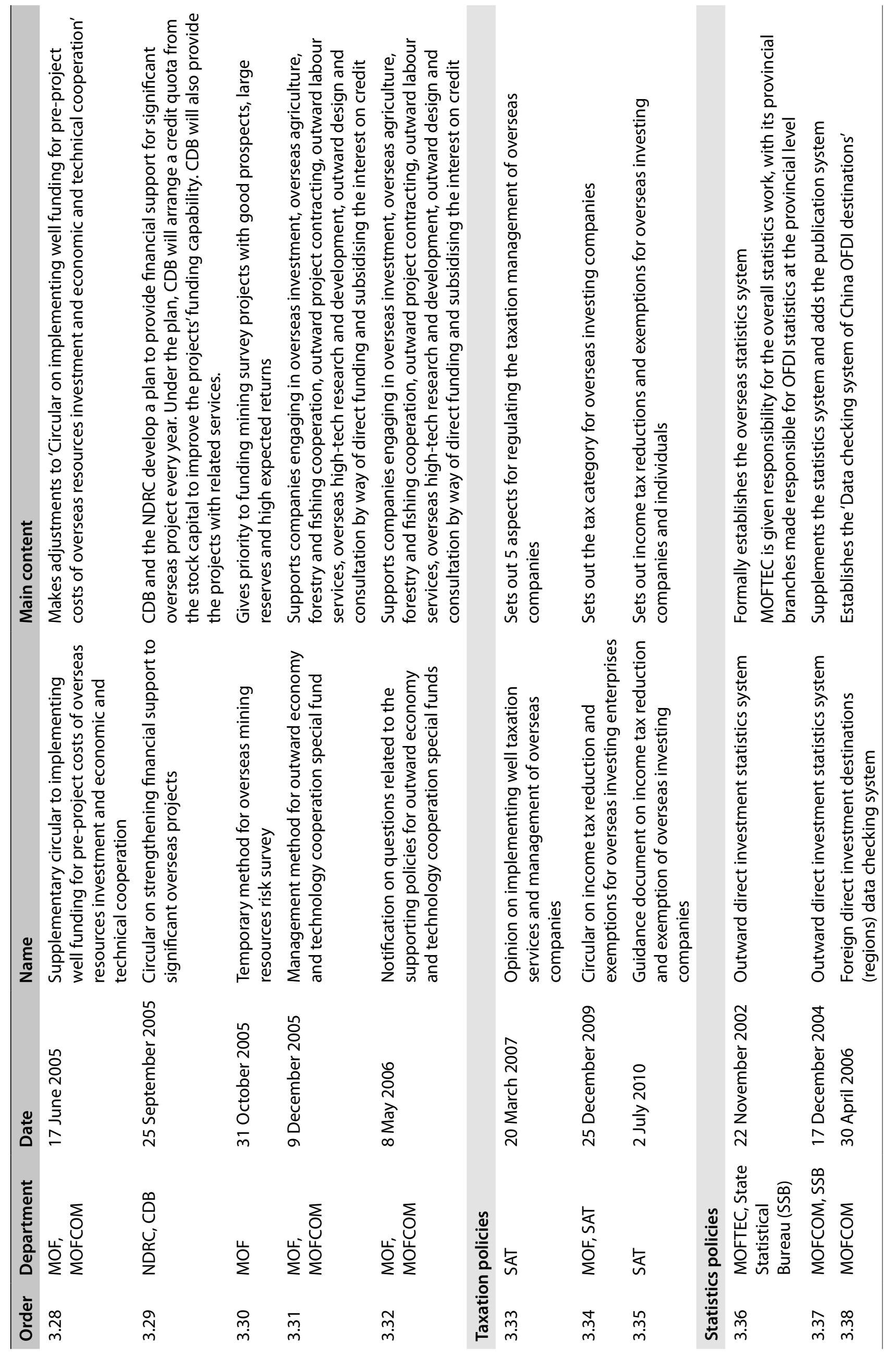




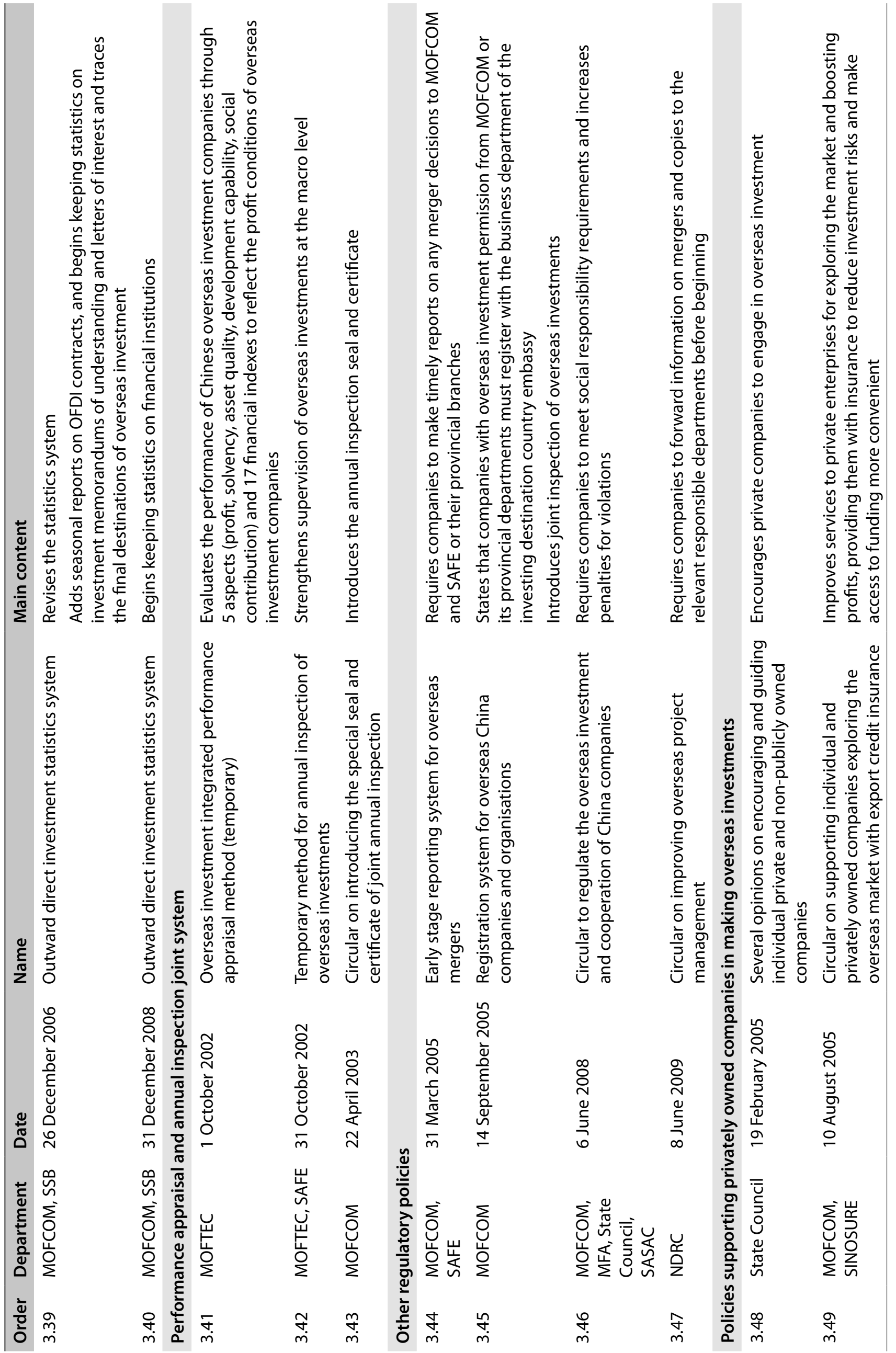



In recent years, in line with China's Going Out strategy announced in 2000, China's overseas investment activities have increased greatly and at increasing rates. By the end of 2009, the total value of China's outward foreign direct investment had reached US\$5.6 billion. Policies have played strong supporting roles in bringing about this trend by facilitating and encouraging Chinese companies to make overseas investments. This working paper summarises these policies based on an analysis of policy changes over time and identifies the main drivers of these changes. It also highlights some key research questions of relevance to deepening understanding of the impacts of Chinese trade and investment in Africa.

The project 'Chinese trade and investment in Africa: Assessing and governing trade-offs to national economies, local livelihoods and forest ecosystems' project, launched in March 2010, aims to advance understanding of the social, economic and environmental impacts of Chinese investment in commodities or sectors affecting forests and livelihoods in Africa (e.g. timber, mining, agriculture), and to strengthen the capacity of decision-makers in government, civil society and the private sector to enact reforms to maximise social and economic benefits while minimising adverse effects. 